\title{
Behavioral Exploitation Antitrust in Consumer Subprime Mortgage Lending
}

\author{
Max Huffman* \& Daniel B. Heidtke**
}

We analyze whether antitrust provides a favorable alternative and perhaps superior approach to regulating consumer subprime mortgage lending. Behavioral exploitation antitrust targets commercial conduct of the sort that was observed in consumer subprime mortgage lending in the years leading up to 2007. The negative effects to welfare of exploitation of the subprime mortgage market are easily observed. Antitrust-based regulation can mitigate those welfare effects. Regulation that does exist, which operates at the level of the individual transaction, may be easily avoided, may be short-sighted, may suffer from enforcement problems explained by public choice theory, and/or may overreach in its capacity to remove consumer choice. We show that antitrust enforcement under a rule of reason approach avoids those pitfalls. However, none of the three primary approaches to antitrust enforcement-prohibitions of anticompetitive conduct by a dominant firm, prohibitions of anticompetitive agreements, and prohibitions of mergers with incipient anticompetitive effects - in their current forms permit resort to antitrust remedies in the consumer subprime mortgage market. We argue that liberalized standards for antitrust enforcement under both Clayton Act section 7 (regulating mergers) and Sherman Act section 1 (regulating concerted conduct), perhaps restricted narrowly to this and closely analogous markets, would be appropriate to gain the benefits of regulation through behavioral exploitation antitrust.

\section{TABLE OF CONTENTS}

I.INTRODUCTION .77

II. WELFARE EFFECTS IN MORTGAGE MARKETS AND FAILURES OF EXISTING

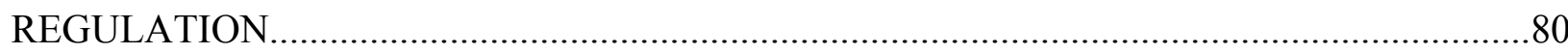

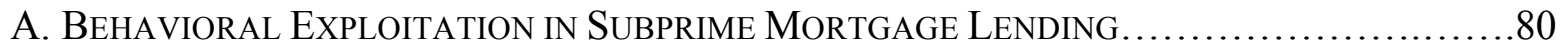

B. The Problems With the Regulatory Status Quo Ante.............................................86

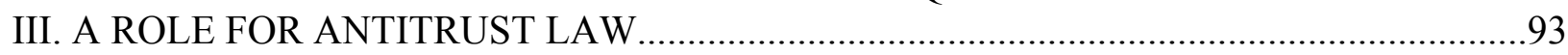

A. Behavioral Exploitation as Bad Antitrust Conduct.................................93

B. Antitrust Avoids the Problems with the Leading

C. Approaches to Consumer Mortgage Regulation.................................97

D. ThE LiMits of BEHAVIORAL EXPLOITATION ANTITRUST ...............................101

IV. MOVING TO BEHAVIORAL EXPLOITATION ANTITRUST ......................106

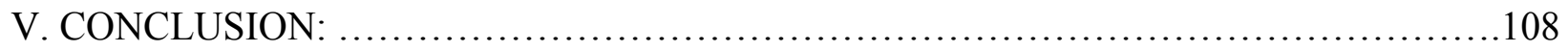

\section{INTRODUCTION}

The grass roots of the 2007 financial crisis were the market for consumer home mortgages. This market was rife with failures, many of which occurred because consumers suffered well-understood limitations on their abilities to maximize their own economic welfare, and lenders knew how to exploit those failures. The market failures created substantial resource 
misallocation: more consumers borrowed more money on different terms than they would have in a market lacking such behavioral exploitation. That resource misallocation took the form of an "asset bubble": more homes were built and sold than would have been in a market in which consumers acted with fuller information and greater ability to act on it.

Regulators proved unable or disinclined to prevent the asset bubble. Some combination of factors - a dereliction of duty, a lack of foresight, a lack of economic rationality, and/or perverse incentives created by the political and regulatory structure - was at play. We accept the proposition that regulator foresight was impossible. On that basis, we seek a means to prevent future crises other than simply more regulation. We propose that behavioral exploitation antitrust may prevent future such asset bubbles in consumer markets. We go further and argue that US-style antitrust law and policy is institutionally superior to the modes of regulation that have been relied on to date.

The root cause of the asset bubble was behavioral exploitation, whereby lenders intentionally exploited consumers' known decision-making biases, creating a market effect. That conduct may give rise to antitrust liability. Antitrust's remedial scheme is more likely to forestall future crises with roots in consumer markets than are other regulatory schemes. As Darren Bush observed in the wake of the financial crisis, "[a]ntitrust law is one of the ingredients which flavors our national economy and ought to be seriously reconsidered in light of its role in helping shape the current state of that economy." "We extend the existing literature on consumer harm from behavioral exploitation by showing that an antitrust remedy may be available, and is superior to other regulatory approaches to this conduct.

Antitrust law exists to protect against the ravages of private enterprise that the market cannot be relied on to avoid - market failures. ${ }^{2}$ There are two primary tools in the antitrust kit that might be employed to prevent financial crises caused by the failure of systemically important firms or groups of firms. First, antitrust has been used to prevent undue concentration by one firm or groups of firms in an industry. At its most extreme and controversial, this marketstructure-oriented approach to enforcement might encourage the forced dismantling of firms in a market that is considered unduly concentrated. Such an approach harkens to the StructureConduct-Performance paradigm, a now disfavored - though in some circles resurgent - school of

\footnotetext{
* Associate Professor and Dean's Fellow, Indiana University Robert H. McKinney School of Law. A draft of this paper accompanied a talk given at the Loyola Consumer Law Review Symposium, "The Continuing Effect of the Mortgage Crisis on Consumers," Loyola University Chicago, School of Law. Thanks to participants at that symposium, participants in a workshop at the Indiana University Robert H. McKinney School of Law, Letha Flint, Matthew Olsen, and Michael Pitts for helpful comments. Thanks also to the editorial staff at the William \& Mary Policy Review and to our blind peer reviewer.

${ }^{* *}$ Fellow, Institute for Consumer Antitrust Studies, Loyola University Chicago, School of Law.

${ }^{1}$ Darren Bush, Too Big to Bail: The Role of Antitrust in Distressed Industries, 77 ANTITRUST L.J. 277, 312 (2010).

${ }^{2}$ Market failures might arise when one firm or a group of firms are able to prevent, or at least to delay, the market's correcting functions. "Market failure" is a technical misnomer for a market response that is simply too slow to protect against substantial short- and medium-term harm. Thus, broad industry collapse might not represent market failure at all, but a necessary adjunct to the establishing of a stronger industry, which will emerge after a period of shake-out. Like Keynes, who famously observed that long-run solutions are of limited value in the real world, we nonetheless consider such a delayed market response to be intolerable. See John MaYnard KeYnes, A Tract on MONETARY REFORM 80 (reprinted, Prometheus Books 2000) ("The long run is a misleading guide to current affairs. In the long run we are all dead."). (Keynes wrote of monetary policy, with specific reference to price inflation in the absence of government regulation, and not of the microeconomic conduct that we consider here.) Antitrust has a place in such a non-failure circumstance as well. It can hasten discipline that the market might provide after time, but that threatens to arrive too late to protect against substantial short- to medium-term harm.
} 
antitrust thought from the middle of the last century. ${ }^{3}$ Middle-ground approaches, including blocking mergers that would lead to unwieldy size and considering merging firms' demonstrated propensity to engage in harmful conduct, remain vibrant and may serve a remedial purpose in consumer subprime markets.

Antitrust's second tool is targeting bad conduct by firms that enables competitive success on bases other than superior efficiency. That bad conduct may lead to, or help to preserve, the same unwieldy market structure that merger review exists to prevent. ${ }^{4}$ It is well understood that bad conduct that leads to or preserves monopoly power may also bring about resource misallocation. That resource misallocation occurs in the case of behavioral exploitation, when demand is stimulated to a level inconsistent with what consumers' actual preferences would be in the absence of the conduct. ${ }^{5}$

We apply behavioral exploitation antitrust to conduct in the consumer subprime mortgage markets that underlay the 2007 financial crisis. We adopt the commonly held understanding of the root cause of the crisis: the sale of millions of mortgage products to consumers in transactions that were either fraudulent or exploited those consumers' inabilities to act in pursuit of their own economic best interest. ${ }^{6}$ The conduct produced short-term success for firms engaged in it. That success spurred competition through similar conduct, leading to an asset bubble. ${ }^{7}$ We will demonstrate here that an antitrust-based approach could prevent the grass-roots conduct that led to market failure. There is reason to hope that our arguments might be

\footnotetext{
${ }^{3}$ See generally Darren Bush, Too Big to Bail: The Role of Antitrust in Distressed Industries, 77 ANTITRUST L.J. 277, 281-88 (2010) (describing the Structure-Conduct-Performance paradigm of antitrust enforcement). Serious thought has been given in very recent years to imposing structural limits in financial markets. One author notes: "both the Dodd-Frank Act and the [EU Vickers Commission] Report make some 'structural reform' proposals for solving the problem of too-big-to-fail." Abel Mateus, "Too Big to Fail": Banking Regulatory Reform and What Still Needs to be Done, 7 COMP. POL'Y INT'L 22, 23 (2011). Under modern approaches, however, U.S. antitrust law is limited to preventing mergers leading to unwieldy size, and has no tools for limiting or reducing firm size when growth is organic. Others have proposed a role for antitrust in limiting firm size, with an eye toward the systematic problems of dominant firms' stumbling and failing; but those approaches require changes in enforcement philosophy by both enforcement agencies and courts. See Jesse W. Markham, Jr., Lessons for Competition Law from the Economic Crisis: The Prospect for Antitrust Responses to the "Too Big to Fail" Phenomenon, 16 FORDHAM J. CORP. \& FIN. L. 261, 262 (2011) ("Antitrust law could make a greater contribution in resolving this public-policy problem if Congress enacted or the judiciary forged more robust rules preventing and dismantling unwieldy corporate size in excess of any plausible scale efficiency justification.”).

${ }^{4}$ See United States v. Aluminum Co. of Am., 148 F.2d 416, 430-31 (1945) (discussing a firm's ability to acquire monopoly power through conduct).

${ }^{5}$ See Oren Bar-Gill, The Law, Economics and Psychology of Subprime Mortgage Contracts, 94 Cornell L. ReV. 1073, 1079-80 (2009) (noting the "demand-side market failure" that occurs when borrowers are myopic, optimistic, and otherwise economically irrational, leading them to "'demand' complex deferred-cost loans"); $c f$. Roger D. Blair \& Jeffrey Harrison, Rethinking Antitrust Injury, 42 VAND. L. REV. 1539, 1561-65 (1989) (predatory pricing another species of bad antitrust conduct - causes resource misallocation as prices are dropped below their competitive levels).

${ }^{6}$ Oren Bar-Gill noted in 2009 the growth of the subprime mortgage market over the five years prior to 2007, with 3 million subprime loans "originated" - sold - in 2006, and the total market value of all subprime loans exceeding one trillion dollars. The Law, Economics, and Psychology of Subprime Mortgage Contracts, 94 CoRNELl L. REv. 1073, 1074 (2009). See generally Andrew Ross Sorkin, Too Big to Fail (2010); National Commission on the Causes of the Financial and Economic Crisis in the United States, Final Report (2011).

${ }^{7} C f$. Mark Zandi, "Fannie and Freddie don't deserve the blame for bubble," Jan. 24, 2011, Wash. Post, available at http://www.washingtonpost.com/realestate/fannie-and-freddie-dont-deserve-blame-for-bubble/

2012/01/23/gIQAn3LZMQ_print.html (visited Jan. 24, 2011). Zandi noted the phenomenon of "rapaciously expanding private lenders" offering "low rates and increasingly aggressive terms to borrowers. In 2006, almost half the loans made by private lenders required no down payment and no documentation." Id.
} 
extended, and that antitrust enforcement promises to be a successful preventative strategy for future asset bubbles that rely on consumer spending. ${ }^{8}$

In Part II we first define behavioral exploitation and show how it occurred and caused harm in the consumer subprime mortgage markets. We then discuss the regulatory protections that exist and proved to be ineffective in preventing the 2007 crisis. We explain why those leading approaches to consumer mortgage regulation proved insufficient to prevent the subprime mortgage lending that led to the crisis. Part III discusses a behavioral exploitation antitrust claim for conduct in these markets. Although the behavioral exploitation antitrust claim is a natural fit for the conduct in consumer subprime mortgage markets, we conclude the claim is not achievable under the current state of antitrust law. We thus devote Part IV to proposals for changing the law, either through legislation, common-law interpretation, or regulation.

\section{WELFARE EFFECTS IN MORTGAGE MARKETS AND FAILURES OF EXISTING REGULATION}

Behavioral exploitation was common in consumer subprime mortgage transactions prior to 2007. ${ }^{9}$ It caused harms to consumers, which aggregated to create market effects. Resources were misallocated as more consumers borrowed more money to buy more houses than they would have had they followed utility maximizing strategies in a situation lacking behavioral exploitation. And the regulatory schemes in place suffered from flaws, including shortsightedness, regulatory capture, easy circumvention, and removal of consumer choice. Further, the body of statutory provisions regulating mortgage transactions has been the subject of seemingly steady reform and amendment, requiring almost constant study to remain abreast of the current state of the law. ${ }^{10}$ The primary response to the financial crisis, the Dodd-Frank Act, does not solve those problems.

\section{A. Behavioral Exploitation in SubPrime Mortgage Lending}

Behavioral exploitation is intentionally exploiting known biases in consumer decisionmaking. ${ }^{11}$ The theory rests on an understanding of those consumer marketplaces, like those for subprime mortgages, as being characterized by sophisticated repeat-player merchant sellers and relatively naïve end-user purchasers. ${ }^{12}$ Consumer credit markets are understood to possess these

\footnotetext{
${ }^{8}$ Our argument relies on asymmetries in either information or sophistication between two parties to an ostensibly consensual transaction. It is readily applicable to consumer transactions that "are characterized by an asymmetry between the two parties: the seller of a good or the provider of a service on the one hand and the consumer on the other. One party is usually a highly sophisticated corporation, the other - an individual, prone to the behavioral flaws that make us human.” Oren Bar-Gill, Seduction by Plastic, 98 Nw. U.L. REv. 1373, 1373 (2004). We do not in this paper extend the argument beyond consumer marketplaces.

${ }^{9}$ We do not study the market after the financial crisis.

${ }^{10}$ See generally, T. Thomas Cottingham, III, Mortgage and Asset Backed Securities Litigation Handbook § 5:1, detailing the amendments to TILA, including: HOEPA, and then a period of several months in which TILA and the HOEPA amendments were amended by the Mortgage Disclosure Improvement Act of 2008 (MDIA), and the Emergency Economic Stabilization Act of 2008 (EESA), which further amended the MDIA's amendments to TILA.

${ }^{11}$ Max Huffman, Marrying Neo-Chicago with Behavioral Antitrust, 78 ANTITRUST L.J. 105, 128 (2012). See also Matthew A. Edwards, The Rebate Rip-off: New York's Legislative Responses to Common Consumer Rebate Complaints, 29 PACE L. REV. 471, 476 (2009) (referring to rebate programs as "behavioral exploitation," which take advantage of consumers' inertia, leading to their failures to redeem); Matthew A. Edwards, The FTC and New Paternalism, 60 ADMIN. L. REV. 323, 353 (2008) (giving examples of payday lending, inducement of supermarket impulse purchases, and mail-in rebates).

${ }^{12}$ Huffman, supra note 11, draft at 38-40.
} 
characteristics. ${ }^{13}$ In particular, consumer subprime mortgage transactions frequently involve borrowers with the dual characteristics of below-average education and limited experience with transactions in the market. ${ }^{14}$

Those exploitable biases, sometimes called decision-making heuristics, are mental short cuts that facilitate rapid decision-making, but frequently cause consumers to deviate from their utility maximizing decision paths. ${ }^{15}$ A marriage of economics, social psychology, and management theory, termed behavioral economics, has demonstrated that individuals systematically deviate from utility maximizing conduct - sometimes by being more altruistic than their utility functions would predict, sometimes by exhibiting less willpower than their utility functions would predict, and sometimes by exhibiting cognitive short-comings. ${ }^{16}$ Those three deviations from utility-maximizing-conduct have been called bounds on consumer rationality. ${ }^{17}$ They give rise to a host of demonstrated cognitive biases. ${ }^{18}$ Some empirically observed phenomena are highly relevant to consumer lending markets, including "hyperbolic discounting" or "myopia" - the tendency to ignore long-term costs and benefits so that decisions are made on the basis of short-term cost-benefit analyses ${ }^{19}$ - and the "optimism bias," which causes a consumer to discount statistically likely future harm and over-rely on statistically unlikely future benefits. ${ }^{20}$

\section{THE REALITY OF BEHAVIORAL EXPLOITATION}

Behavioral economics arrived late to the party. The real-world practice of behavioral exploitation stems from knowledge gained over many decades of study that is well documented in the market literature. Too few in the fields of law and economics, and in particularly in the antitrust, realms, have seen fit to study the business and management theory literature when developing legal rules. ${ }^{21}$

${ }^{13}$ See Oren Bar-Gill \& Elizabeth Warren, Making Credit Safer, 157 U. PA. L. REV. 101, 169 (1998); see also Edward J. Janger \& Susan Block-Lieb, Consumer Credit and Competition: The Puzzle of Competitive Credit Markets, 6 EuR. CoMP. J. 68, 70-71 (2010).

${ }^{14}$ See Laurie A. Burlingame, A Pro-Consumer Approach to Predatory Lending: Enhanced Protection Through Federal Legislation and New Approaches to Education, 60 CONSUMER FIN. L.Q. 460, 462 (2006).

${ }^{15}$ See Daniel Kahneman, Thinking FAST AND Slow 25 (2011) (subconscious "System 1" decisions are "usually accurate" and are "swift and generally appropriate," but subject to "systematic errors").

${ }^{16}$ See Christine Jolls et al., A Behavioral Approach to Law \& Economics, 50 STAN. L. REV. 1471, 1476-79 (1998).

${ }^{17}$ See id.

${ }^{18}$ Empirical study has demonstrated myriad cognitive biases, many of which are closely related to long-established biases. Wikipedia contains an impressive list. See List of Biases in Judgment and Decision Making, WiKIPEDIA, (February 9, 2012) en.wikipedia.org/wiki/List_of_cognitive_biases. More in-depth discussion can be found in sources including Daniel Kahneman, Thinking Fast and Slow (2011), and Dan Ariely, Predictably Irrational (2008).

${ }^{19}$ See Oren Bar-Gill, Seduction by Plastic, 98 Nw. U. L. REV. 1373, 1396 (2004).

${ }^{20}$ See id.

${ }^{21}$ Spencer Waller has recognized this problem. In 2001, Professor Waller noted the oddity that we relied so much on economic teaching rather than lessons from business and management theory. Spencer W. Waller, The Language of Law and the Language of Business, 52 CASE WESTERN RES. L. REV. 283, 283-85 (2001). He was right to do so. As he pointed out in 2001, while economists found themselves hung up with theoretical concerns over whether certain practices could possibly cause harm, by, for example, creating market power that enabled a firm to raise prices or decrease output or quality, business persons recognized that, in the real world, just that was going on. See Spencer Weber Waller, The Language of Law and the Language of Business, 52 CASE W. RES. L. REV. 283, 316-28 (2001). It is an interesting aside that the expert regulators tend to come either from legal or economic backgrounds, but much less from business backgrounds. The FTC has a bureau of economics, populated with, according to a recent statistic, some $70 \mathrm{PhD}$ economists, but no comparable bureau populated with MBAs. See www.ftc.gov (last visited April 2, 2012). 
Merchants have studied means to exploit hyperbolic discounting, the optimism bias, and other cognitive biases when contracting with consumers. Another demonstrated bias causes consumers to make decisions on the basis of salient, noticeable characteristics over characteristics that are less pronounced. Consumers may borrow money on the basis of the interest rate or down payment rather than penalties for non-repayment. The endowment effect or ownership bias increases the value to us of what we have relative to what we do not have. Taken together, a merchant might induce a soft (psychological) commitment to a transaction by quoting a low price before interposing other expenses. This is drip pricing or shrouding, a well-studied technique of exploiting cognitive bias to induce consumers to pay more for the product or service than they would if presented with all the costs up front. ${ }^{22}$ Hyperbolic discounting and optimism biases come into play here as well. If future costs are uncertain, consumers can be expected to envision best-case scenarios or ignore future costs altogether in their decision-making.

Financial transactions demonstrate the behavioral exploitation problem in particularly stark fashion. Financial transactions are much less likely (than, for example, the development, advertising and marketing of products or services) to be characterized by idiosyncratic goals on the parts of consumers. Consumers are unlikely to gain any utility from higher-than-necessary interest rates or fees. A 2009 study of pricing practices concluded that drip pricing is one of two practices with the "greatest potential to cause harm" by inducing consumers to enter transactions they would not have entered had the prices been fully disclosed up front. ${ }^{23}$ Drip pricing and price shrouding succeed by increasing willingness to pay, exploiting the endowment effect, and by obfuscating the actual price. A consumer may learn about the actual price after the consumer is committed to the transaction, or may never learn the actual price.

It requires little extension of these studies to see their impact on consumer subprime mortgage transactions. Scholars have identified three dominant characteristics of consumer subprime mortgage transactions. According to Oren Bar-Gill, consumer subprime mortgage transactions are characterized by supra-normal cost deferral and an "exceedingly high level of complexity." Neither can be explained at the level that they occur in subprime lending under an assumption that both parties act rationally to maximize their utility. ${ }^{24}$ Others have observed that subprime borrowers are, on average, less sophisticated, in terms both of education and experience in the market, than borrowers generally. ${ }^{25}$

Supra-normal cost deferral is analogous to drip pricing techniques. A lender can charge more on a transaction if the up-front price is low in the form of a low - even zero - down

\footnotetext{
${ }^{22}$ See Amanda Reeves \& Maurice Stucke, Behavioral Antitrust, 86 IND. L.J. 1527, 1541 (2011) (defining drip pricing). Cf. Robert B. Cialdini, Influence: Science \& Practice 61-67 (4th ed. 2001) (describing larger impacts of inducing commitment with regard to small initial decisions). The United Kingdom's Office of Fair Trading has concluded that drip pricing is one of the two most pernicious pricing practices by causing purchasers to spend more than they wished (in the absence of the full pricing practice) to spend. See UK Office of Fair Trading, "Advertising of Prices," available at oft.gov.uk/OFTwork/markets-work/current/advertising-prices/.

${ }^{23}$ U.K. Office of Fair Trading, "Findings and Outcomes," in Advertising of Prices (Oct. 15, 2009), available at http://www.oft.gov.uk/OFTwork/markets-work/advertising-prices/. Consumers encounter drip pricing on a daily basis, in sales pitches as mundane as "would you like to add a cookie for only $\$ 0.99$ more today?" and as frustrating as "that will be $\$ 60$ for your two checked bags - how would you like to pay for that today?" See, e.g., "Optional service fees \& government taxes," U.S. Airways.com, available at usairways.com/enUS/traveltools/specialneeds/ticketingpolicies/taxesfees.html?c=hp_txt_01120 (last visited Feb. 9, 2012).

${ }^{24}$ Oren Bar-Gill, The Law, Economics and Psychology of Subprime Mortgage Contracts, 94 CORNELL L. Rev. 1073, 1079 (2009).

${ }^{25}$ See, e.g., Laurie A. Burlingame, A Pro-Consumer Approach to Predatory Lending: Enhancing Protection Through Federal Legislation and New Approaches to Education, 60 CONSUMER FIN. L.Q. REP. 460, 462 (2006).
} 
payment. The supra-normal cost-deferral, whereby "in 2005, 2006, and the first half of 2007, the median subprime borrower put no money down, borrowing 100 percent of the purchase price of the house," ${ }^{, 6}$ might produce both of the effects of drip pricing. Before becoming aware of the reality of their obligations, consumer borrowers can become psychologically committed to a transaction and thereby willing to incur greater expense than they otherwise might have been willing to incur. Cost deferral, like drip pricing, has obfuscating effects as well. Because the real cost of a credit transaction depends on time value of money considerations, the more costs are deferred, the more difficult it is for a consumer accurately to calculate the real cost of borrowing.

The obfuscating effect is compounded by complex credit terms that prevail in consumer subprime mortgage transactions. Those may include "multiple, indirectly defined interest rates... "further complicated by maximum adjustment caps." 27 Steffen Huck and Zidong Zhou have concluded that this complexity serves to hide from the consumer the actual price of the credit. Markets operate more efficiently in the presence of information and transparency. A profitmaximizing lender that is able to hide real prices in complex terms will charge higher prices because of the reduced risk that the borrower will shop around. ${ }^{28}$

Finally, the consumer subprime borrower is characterized by limited education and experience, rendering him or her susceptible to exploitation. Education and experience render consumers more able to protect themselves against the harms from behavioral exploitation. ${ }^{29}$ The lack of those advantages leaves the consumer relatively more susceptible. Experience usually will be limited because home mortgage transactions are consummated infrequently in any one borrower's economic lifetime, so consumer borrowers do not have the opportunity to realize their errors and act differently in future transactions. ${ }^{30}$ As lower income borrowers, subprime borrowers may not have the experience of frequent recourse to credit markets in any form. A related characteristic of many subprime borrowers is old age, ${ }^{31}$ which some evidence indicates correlates with reduced cognitive abilities as regards financial transactions. ${ }^{32}$

2.WELFARE EFFECTS: HARMS TO CONSUMERS AND SUBOPTIMAL RESOURCE ALLOCATION

Behavioral exploitation is well understood to cause harm by undermining efficient resource allocation. Consumers are induced to enter transactions they would eschew but for the exploitative conduct, or to enter transaction on terms that they would otherwise consider intolerable. Resources flow to consumers' ostensible, rather than actual, preferences. ${ }^{33}$ That creates a market in which high dollar subprime mortgages may crowd out small dollar prime

\footnotetext{
${ }^{26}$ Oren Bar-Gill, The Law, Economics and Psychology of Subprime Mortgage Contracts, 94 CORNELL L. REV. 1073, 1076 (2009).

${ }^{27}$ Id. at 1078 .

${ }^{28}$ Huck \& Zhou argue: "The adverse effects of poor decisions with regards to search and quality can be made worse through firms' deliberate attempts to make price comparisons and search harder - through complex pricing, shrouding, obfuscation and other means." Huck \& Zhou, Consumer Behavioral Biases in Competition: A Survey, UK Office of Fair Trading, at 7 (2011).

${ }^{29}$ See Huck \& Zhou, supra note 28, at 57-58 (learning and cognitive ability lessen welfare effects of cognitive biases).

${ }^{30}$ Huck and Zhou suggest that ex post detection and realization of errors offers "the biggest scope for alleviating market failures". Huck \& Zhou, supra note 28 at 8.

${ }^{31}$ See Burlingame, supra note 25 at 462.

${ }^{32}$ See Huck \& Zhou, supra note 28 at 58.

${ }^{33}$ See Huck \& Zhou, supra note 28 at 7 (warning of "overproduction of goods that in the end will be thrown away or suboptimal design of products that may have too much of one attribute and too little of another").
} 
mortgages if consumers are induced to enter inappropriate transactions. ${ }^{34}$ Aggregate welfare is thereby diminished. ${ }^{35}$

This effect differs from demand-curve shifting that underlies dynamic competition, whereby, for example, the introduction of the iPad created demand for tablet computers that previously did not exist. ${ }^{36}$ Behavioral exploitation is not a question of introducing and marketing new products, changing consumers' utility functions permanently (or until the next innovation comes along). ${ }^{37}$ Behavioral exploitation is a question of a short-term shift in the demand curve, altering consumers' understandings of their own utility functions long enough to bring about a transaction that cannot be reversed.

Bar-Gill has recognized the welfare effects of the type of behavioral exploitation that we outline here. ${ }^{38}$ He explains how those welfare effects occur in subprime mortgage contracts that "share two suspect features" of cost deferral and complexity we discuss above. ${ }^{39}$ Bar-Gill identified a "demand-side market failure" that occurred when imperfectly rational borrowers "'demanded' complex deferred-cost loans and lenders met this demand." ${ }^{\circ}$ That market failure produced welfare effects in four ways: complexity hindered competition by undermining comparison-shopping; cost-deferral led to increased rates of default with consequent harm to borrowers and third parties (including "the economy at large"); subprime contracts suffered distributive consequences because poor borrowers were uniquely affected; and demand for home mortgage products was artificially inflated. ${ }^{41}$

It is possible to theorize the size of the welfare effect in any individual transaction. Any amount paid on an expected-value basis above the consumer's reservation price in the mortgage transaction should be considered pure wealth transfer to the lender. ${ }^{42}$ (Although it is possible that consumers are willing to pay more in a transaction for the added value of a trusted lender,

\footnotetext{
${ }^{34}$ For another concrete example, behavioral exploitation may produce too much demand for consumer subprime mortgage lending. The supply response will reduce the supply of (for example) student loans and increase their cost relative to subprime mortgage loans.

${ }^{35}$ See Oren Bar-Gill, The Law, Economics, and Psychology of Subprime Mortgage Contracts, 94 CoRnell L. ReV. 1073, 1130 (2009) (noting "welfare cost in the form of allocation inefficiency: borrowers are not matched with the most efficient lender."); Oren Bar-Gill, Competition and Consumer Protection: A Behavioral Economics Account, in Swedish Competition Authority, The Pros and Cons of Consumer Protection (forthcoming), manuscript at 1, 4 (Dec. 2011), (noting that "perceived benefits" of a transaction may deviate from "actual benefits").

${ }^{36}$ See generally J. Gregory Sidak \& David J. Teece, Dynamic Competition in Antitrust Law, 5 J. ComP. L. \& ECON. 581 (2009) (describing the role of dynamic competition in antitrust analysis and the importance of Schumpeterian "product and process innovation").

${ }^{37}$ See Timothy J. Tardiff, Efficiency Metrics for Competition Policy in Network Industries, 6 J. CoMP. L. \& ECON. 957, 962 (2010) (product improvements give rise to outward shift in the demand curve).

${ }^{38}$ Bar-Gill, Competition and Consumer Protection, supra note 35, at 13-16. Scholars have for years observed the market failures associated with information asymmetries, which are closely related to the disparities in sophistication that underlie merchants' abilities to exploit naïve consumers. See, e.g., Richard Craswell, Tying Requirements in Competitive Markets: The Consumer Protection Issues, 62 B.U. L. REV. 661, 671 (1982). Craswell also noted the efficiency loss resulting from this exercise of power. Id. at 672.

${ }^{39}$ Oren Bar-Gill, The Law, Economics and Psychology of Subprime Mortgage Contracts, 94 CORNELL L. Rev. 1073, 1076 (2009).

${ }^{40} I d$. at 1080 .

${ }^{41} I d$. at 1083 .

${ }^{42}$ This definition of the transaction-level welfare loss accommodates the possibility that, but for the behavioral exploitation, the transaction would not have occurred at all. If a consumer borrower is willing to pay $\mathrm{X}$ but the lender is able to convince him or her to pay $\mathrm{X}+1$ (not changing his or her mind, but undermining his or her ability to appreciate the actual cost), the consumer will have paid $\mathrm{X}+1$ for a product he or she values at $\mathrm{X}$ and would gladly exchange for something valued at $\mathrm{X}+1$.
} 
whether in exchange for avoided search costs or due to a perceived quality difference, that effect will be very small. It may also be possible to compare amount paid to reservation price on a lender-by-lender basis, eliminating any effect from brand loyalty.)

Determining exactly what that differential is in a particular transaction is more challenging. One could engage in exit polling-type surveys of consumer borrowers, asking after the transaction was consummated how much the consumer was willing to pay and comparing it to the actual transaction terms. The advantage of this approach is that any such survey would account for factors that may have been unforeseeable prior to the consumer's actually consummating the transaction, such as falling in love with a home that is more expensive than originally anticipated. ${ }^{43}$ It suffers from drawbacks of administrative difficulty and possible unreliability.

A second approach would be to compare the loan terms of the consummated transaction against those of transactions that the consumer eschewed. A consumer borrower who chooses an adjustable-rate mortgage over a fixed-rate mortgage that is less expensive on an expected value basis may have been behaviorally exploited. This approach suffers two drawbacks. First, many subprime borrowers fail to qualify for an array of lending options, eliminating alternatives before the consumer is able to choose. Second, there are a variety of factors that might explain a borrower's choice of loan terms, even under an assumption of rational choice. For example, a borrower with no money available for a down payment but who reasonably expects to come into money in the medium-term might purchase immediately (to take advantage of low prices, or so as not to lose a particularly attractive property) on terms that would be unattractive for most borrowers, but avoid the problems of the onerous loan terms by paying the loan off early.

Welfare effects are more readily determined by looking across the market than by looking at any one transaction. Determining the costs of particularly pernicious loan characteristics gives a basis for approximating market-wide welfare effects. Eric Stein conducted an early study that preceded the most substantial excesses in subprime mortgage lending over the past decade. His report estimated "that U.S. borrowers lose \$9.1 billion annually to predatory lending practices," employing a definition of predatory lending that included conduct within the ambit of behavioral exploitation. ${ }^{44}$ Of the lending practices studied, "equity stripping" - the charging of fees, credit insurance, and prepayment penalties represented $2 / 3$ of the annual loss. Stein's description of these practices as including fees that are "painless at closing" but lasting "forever" invokes the salience and optimism biases and hyperbolic discounting, as well as the drip pricing, shrouding, and obfuscation techniques for exploiting them.

\section{DECEPTION COMPARED}

Behavioral exploitation is a close cousin of deception, the practice of inducing a transaction on the basis of material misrepresentations (or omissions that operate as misrepresentations) that has long been regulated at common law and by both federal and state statute. ${ }^{45}$ A simple example illustrates the difference between the two. A materially false statement of, or a material omission to state (in a context where the omission creates a

\footnotetext{
${ }^{43}$ This effect may itself be the result of behavioral exploitation by the seller of the home or a real estate agent.

44 See Eric Stein, Quantifying the Economic Cost of Predatory Lending, COALITION FOR RESPONSIBLE LENDING REPORT 2 (Rev'd ed. Oct. 2001).

${ }^{45}$ See generally Michael M. GreEnfield, COnSumer Transactions 6-183 (2009) (discussing federal and state regulation of deception)
} 
misimpression), a transaction term is deceptive. ${ }^{46}$ Thus, a deceptive lender might say "that's everything," but later include a fee that was not disclosed. By contrast, an accurate statement of the same transaction terms, in a context that renders the consumer unable to appreciate its importance, is behavioral exploitation. A behaviorally exploitative lender might disclose the fee only at the very last minute, when the consumer is psychologically and practically (having, for example, agreed to the underlying purchase transaction) committed to proceed.

Deception certainly took place in the market for consumer subprime home mortgages leading up to the 2007 financial crisis. The U.S. Financial Crisis Inquiry Commission report, among other examples, describes occurrences of consumers who thought they agreed to one set of loan terms and signed papers reflecting other loan terms. ${ }^{47}$ This conduct creates harm in the same way as behavioral exploitation: the deceived consumer enters a transaction he or she otherwise would not consummate, creating an economy-wide welfare loss. ${ }^{48}$

\section{B. The Problems With the Regulatory Status Quo Ante}

A hodge-podge of targeted, consumer-protection based, regulation developed in the years leading up to the financial crisis. The existing consumer protection and remedial structure remains insufficient, inefficient, and bewildering. One court expressed regret evidencing insufficiency of the current state of regulation of the mortgage lending industry: "The power to curb predatory practices lies either in consumer education or with Congress; as a court of limited jurisdiction, I may only enforce the laws as written, not as I would wish they were written." 49

1. EXISTING FEDERAL AND STATE MORTGAGE LENDING REGULATION

In broad terms, existing mortgage lending regulation may be placed in one of the following categories: (1) federal disclosure statutes, (2) statutes regulating unfair or deceptive acts or practices, and (3) state law remedies. First, federal regulation of grass-roots transactions primarily revolves around two statutes: the Truth in Lending Act (TILA), ${ }^{50}$ and the Home Ownership and Equity Protection Act (HOEPA). ${ }^{51}$ The Federal Trade Commission Act, which regulates "unfair or deceptive acts or practices," provides another basis for protection against harmful lending practices. Lastly, state law often provides a means through which to challenge unfair conduct, yet in a way that is frequently redundant to federal regulation.

Although the failure of existing mortgage lending regulation alone cannot entirely account for the subprime mortgage meltdown, the existing regulations could not stem the tide of loosened lending practices, outright fraud, and behavioral exploitation in the years preceding the financial crisis. ${ }^{52}$ For instance, TILA requires and regulates lender disclosures at the time of a

\footnotetext{
${ }^{46}$ See supra Part II.

${ }^{47}$ See Financial Crisis Inquiry Report at 7-8, 12; Bernstein Senate Testimony 3.

${ }^{48}$ Maurice E. Stucke, When a Monopolist Deceives, 76 AnTITRUST L.J. 823 (2010).

${ }^{49}$ Parker v. Long Beach Mort., 534 F. Supp. 2d 528, 530 n.2 (E.D. Pa. 2008). See generally Bryce, Foreclosure Developments, Mortgage Fraud, Counterclaims and Defenses, 64 CONSUMER FINANCE L.Q. RPT. 1 (Spring 2010).

${ }^{50}$ Truth in Lending Act ("TILA"), 15 U.S.C.A. $§ 1601$ et seq.

${ }^{51}$ Home Ownership and Equity Protection Act of 1994 ("HOEPA"), 15 U.S.C.A. $\S \S 1602(a a), 1610,1639$, and 1640 .

${ }^{52}$ Christopher E. Ware, Laura Gramling Perez, Main Street Meets Wall Street: The Mortgage Meltdown, 80-DEC Wis. Law. 8 (Dec. 2007)(“Alone, increased demand for homes, low interest rates, risk-shifting investment vehicles, aggressive or fraudulent lending, creative financing, or lax oversight would not have caused the collapse. Together, however, these factors shifted priorities in the mortgage market, and then cause the mortgage problems that are at the forefront of the news.").
} 
consumer loan application, including those for home mortgage loans. ${ }^{53}$ Indeed, the purpose of TILA is to "protect consumers from inaccurate and unfair credit practices and ... assure a meaningful disclosure of credit terms ... [to] avoid the uninformed use of credit." above, a behaviorally exploitative lender, unlike a deceptive lender, would likely comply with TILA by disclosing certain fees or terms. However, that lender will make required disclosures after the consumer is psychologically and practically committed to proceed. Thus, TILArequired disclosures would do little. TILA's purpose would be defeated, where a lender offers such terms in a context in which the consumer is unable to appreciate their importance.

Another federal disclosure statute, HOEPA, amended TILA to respond more directly to so-called predatory lending in the mortgage market. ${ }^{55}$ Whether a mortgage is subject to HOEPA's increased regulation "is determined by triggers related to a loan's annual percentage rate or its points and fees, rather than any definition of 'predatory lending'." ${ }^{56}$ Those triggers proved easy to avoid, permitting creditors to escape HOEPA's increased disclosure requirements. "[L]enders make loans very close to the triggering thresholds, but low enough to avoid the trigger," "offer open lines of credit as opposed to closed-end loans," and charge "junk fees" for "services that are related to, but technically independent of, the mortgage." 57 This ability to end-run the statutory requirements limits HOEPA's effectiveness from a consumer protection standpoint.

The Federal Trade Commission Act is a third basis for protection against harmful lending practices. The FTC has authority to challenge "unfair or deceptive acts or practices." The FTC's unfairness authority generally has been applied in rulemaking, defining specific instances of conduct that may be enjoined as unfair. Deception is defined according to precedent and administrative guidance to include conduct that is likely to mislead a consumer acting reasonably under the circumstances. ${ }^{59}$ The FTC has been successful in reaching settlements including restitution in cases of deception. The FTC Act remedy promises only limited effectiveness for two reasons. First, only the FTC has standing to enforce the FTC Act, precluding consumer and competitor plaintiffs from suing. Second, the reasonableness element of a deception claim is unlikely to be made in a case of behavioral exploitation, which by definition relies on economically irrational - hence, "unreasonable" - conduct. ${ }^{60}$

State law, another possible source of consumer protection, is frequently redundant and often relies on duties imposed by federal statute. ${ }^{61}$ For example, statutorily unfair or deceptive

\footnotetext{
${ }^{53} 15$ U.S.C.A. $\S 1601$ et seq.; see also Reg. Z § 226.19 (requiring lenders is to give early estimated disclosures at the time of the loan application).

${ }^{54} 15$ U.S.C.A. § 1601(a). See Dee Pridgen, Putting Some Teeth in TILA: From Disclosure to Substantive Regulation in the Mortgage Reform and Anti-Predatory Lending Act of 2010, 24 Loy. Cons. L. Rev. 615, 617 (2012) (TILA "took a pure disclosure approach").

${ }^{55}$ Home Ownership and Equity Protection Act of 1994 (“HOEPA"), 15 U.S.C.A. §§ 1602(aa), 1610, 1639, and 1640 .

${ }^{56}$ Letter from Edward M. Gramlich, Member of the Board, Federal Reserve to The Honorable Phil Gramm, Chairman of Committee on Banking, Housing and Urban Affairs, United States Senate, dated April 28, 2000; available at: http://banking.senate.gov/docs/reports/predlend/fed.htm.

${ }^{57}$ Burlingame, supra note 14 at 467; Nicholas Bagley, 79 N.Y.U. L. REV. 2274, 2282 (2004).

${ }^{58} 15$ U.S.C. $\$ 45(\mathrm{a})(1)$.

${ }^{59}$ In re International Harvester, 104 F.T.C. 949 (1984).

${ }^{60}$ It is not logically necessary that "economically irrational" be equated to "unreasonable." Proof that a consumer "acted in a way consistent with the broad range of ordinary or average people" would suffice to render that conduct reasonable under International Harvester. Id.

${ }^{61}$ In re International Harvester, 104 F.T.C. 949 (1984).
} 
acts and practices claims may simply adopt the standards established by interpretations of the Federal Trade Commission Act. ${ }^{62}$ Similarly, some states provide that compliance with TILA disclosures is an affirmative defense to liability under state law. ${ }^{63}$ Yet, commentators do recognize some states' proactive role in regulating consumer-lending practices. ${ }^{64}$

State laws can provide broader protections than federal law in two primary ways. First, state and local laws may increase restrictions on mortgage lenders and apply to a wider spectrum of loans. ${ }^{65}$ Second, state claims may expand the nature of the right of action available. Consumers and state attorneys general lack standing to sue for a violation of the Federal Trade Commission (FTC) Act, but will frequently be granted standing for the same claim brought under state law. Finally, state claims may also arise under the common law of fraud and misrepresentation. Such claims require proof of a misrepresentation of fact by the mortgagee and reasonable reliance by the consumer borrower. ${ }^{66}$

In 2003, however, the Office of the Comptroller of the Currency, a banking regulator, preempted state efforts to regulate the lending practices of national banks. ${ }^{67}$ States were prevented from outlawing loan terms such as balloon payments, negative amortization, late fees, and prepayment penalties, all of which represent the dual characteristics of complexity and deferred cost and capitalize on consumer decision-making biases. ${ }^{68}$ Thus, state laws suffer the same shortcomings as those federal regulations to which they are redundant, and have largely been prevented from going much further.

\section{PREDICTABLE LIMITATIONS}

Much of this regulation was well-intentioned, designed to accomplish narrow and legitimate purposes, and had been in place long before the financial crisis. In fact, TILA was initially enacted in $1968 .{ }^{69}$ Nevertheless, the existing regulations were insufficient and unable to account for changing market conditions, deregulation, and ill-preparedness on behalf of key policy makers. $^{70}$

\footnotetext{
${ }^{62}$ See, e.g., Mass. Gen. Laws Ann. Ch. 93A, § 2 (outlawing unfair methods of competition and unfair or deceptive acts or practices and adopting FTC interpretations of FTC Act $\S 5$ to assist in the interpretation of this section).

${ }^{63}$ See, e.g., Consumer Credit Protection Act, $\$ 102$ et seq., 15 U.S.C.A. $§ 1601$ et seq.; S.H.A. 815 ILCS 505/1 et seq.; see also MorEquity, Inc. v. Naeem, 118 F. Supp. 2d 885, 893 (N.D. Ill., Oct. 25, 2000) (citing Jackson v. South Holland Dodge, Inc., 312 Ill. App. 3d 158, 167, 244 Ill. Dec. 835, 726 N.E. 2d 1146 (1st Dist. 2000) (holding when a creditor is exempt from TILA liability, the creditor is also exempt from Consumer Fraud Act liability.).

${ }^{64}$ See Burlingame, supra note 14, at 468-69 (discussing the North Carolina's anti predatory-lending statute).

${ }^{65}$ Cottingham, Mortgage and Asset Backed Securities Litigation Handbook, §5:8 (Nov. 2011). Detailing, for example, the Georgia Fair Lending Act (Ga. Code Ann. §§ 7-6A-1, et seq.), which initially sought to impose nearly unlimited liability on assignees of many Georgia mortgage loans.

${ }^{66}$ Martin C. Bryce, Jr., Foreclosure Developments, Mortgage Fraud, Counterclaims and Defenses, CONSUMER FinANCE LaW QuARTERLy RePORT, Spring 2010; Citing as examples: Hunt v. U.S. Tobacco Co., 538 F.3d 217, 224-26 (3d Cir. 2008) (Pennsylvania's Unfair Trade Practices and Consumer Protection Law); Cattie v. Wal-Mart Stores, Inc., 504 F. Supp. 2d 939, 947 (S.D. Cal. 2007) (California's Unfair Competition Law); Peltier Enter., Inc. v. Hilton, 51 S.W. 3d 616, 624 (Tex. App. 2000) (Texas' Deceptive Trade Practices Act); Lidecker v. Kendall College, 194 Ill. App. 3d 309, 314 (1990)(Illinois' Consumer Fraud and Deceptive Business Practices Act); Zeeman v. Black, 156 Ga. App. 82, 87 (1980) (Georgia Fair Business Practices Act); Sanders v. Francis, 277 Or. 593, 561 P.2d 1003 (1977) (Oregon's Unlawful Trade Practices Act).

${ }^{67}$ See Arthur E. Wilmarth, Jr., The Financial Services Industry's Misguided Quest to Undermine the Consumer Financial Protection Bureau, 31 REV. BANKING \& FIN. L. 881, 931 (2012).

${ }^{68}$ See Burlingame, supra note 14, at 473.

${ }^{69}$ Title I of the Consumer Credit Protection Act, Pub. L. 90-321, 82 Stat. 146, enacted June 29, 1968.

${ }^{70}$ Financial Crisis Inquiry Commission, Report on the Causes of the Financial Crisis (Jan. 27, 2011); available at: http://fcic-static.law.stanford.edu/cdn_medialfcic-news/2011-0127-fcic-releases-report.pdf ("The Commission
} 
Although disclosure statutes such as TILA and HOEPA were designed to prevent "the uninformed use of credit," or practices," 72 the existing regulation gives rise to what is best described as "whack-a-mole" problems. That is, the existing regulation resolved only problems that were known or foreseeable and could not resolve "unknown unknowns." 73 Indeed, discussing regulation targeting the downstream financial industry, Darren Bush noted the problem with reactionary, rather than anticipatory, regulation. "[T]he missing piece in this discussion of economic crises is an examination of the ex-ante regulation of failed markets and the economy as a whole."74 A regulatory scheme that avoids this trap would enable a challenge to conduct that threatens harm, before that harm is realized.

In addition, changing market conditions likely exposed the reactionary nature of the existing regulations. For instance, rapidly rising property prices (attributed to years of low interest rates) increased the temptation for borrowers to misrepresent their circumstances on applications in order to qualify for loans. ${ }^{75}$ On the other side, loan originators were encouraged to create more loans by the ability to retain little or no exposure on those loans by packaging and selling loans as investment devices. The former aspect of the market would likely decrease the effectiveness of disclosure statutes. ${ }^{76}$ The latter, which has acquired the epithet, "originate-todistribute," 77 switched the focus to the fees from creating and packaging loans as investment devices, as opposed to focusing on the quality of the underlying loans. ${ }^{78}$

concluded that the crisis was avoidable and was caused by: Widespread failures in financial regulation, including the Federal Reserve's failure to stem the tide of toxic mortgages; Dramatic breakdowns in corporate governance including too many financial firms acting recklessly and taking on too much risk; An explosive mix of excessive borrowing and risk by households and Wall Street that put the financial system on a collision course with crisis; Key policy makers ill prepared for the crisis, lacking a full understanding of the financial system they oversaw; And systemic breaches in accountability and ethics at all levels.").

${ }^{71} 15$ U.S.C.A. $\S 1601(\mathrm{a})$.

7215 U.S.C. $\$ 45$.

${ }^{73}$ See Darren Bush, Too Big to Bail: The Role of Antitrust in Distressed Industries, 77 ANTITRUST L.J. 277,278 (2010). We borrow the phrase "unknown unknowns" from then-Defense Secretary Donald Rumsfeld's characterization of threats from Iraq (another phenomenon that likely presents whack-a mole characteristics). See Donald H. Rumsfeld, DoD News Briefing, Feb. 12, 2002, http://www.defense.gov/transcripts/ transcript.aspx?transcriptid=2636.

${ }^{74}$ Bush, Too Big to Bail, at 278.

75 Andrew J. Ceresney, Gordon Eng, Sean R. Nuttall, Regulatory Investigations and the Credit Crisis: The Search for Villains, 46 AM. CRIM. L. REV. 225, 236-37 (2009).

${ }^{76}$ Designed to protect consumers, TILA aims to provide consumers with a "meaningful disclosure of credit terms," but has no impact on consumers' fraudulently filling out credit applications.

77 See Peter H. Hamner, The Credit Crisis and Subprime Litigation: How Fraud Without Motive "Makes Little Economic Sense", 1 U. PUERTO Rico BuS. L.J. 103, 117 (2010) (discussing the "originate-to-distribute" and "subprime lawsuit narrative").

${ }^{78}$ Id. (citing Frederic S. Mishkin, Governor of the Bd. Of Governors of the Federal Reserve System, Speech at the U.S. Monetary Policy Forum, New York: On “Leveraged Losses: Lessons from the Mortgage Meltdown” (Feb. 29, 2008) http:// www.federalreserve.gov/newsevents/speech/mishkin20080229a.htm (last visited Oct. 29, 2012) (in which Frederic Mishkin discusses the misaligned incentives of lenders)); see also Ben Bernanke, Chairman of the Bd. Of Governors of the Federal Reserve System, Address at the Federal Reserve Bank of Chicago's Annual Conference on Bank Structure and Competition, Chicago, Illinois: Risk Management in Financial Institutions (May 15, 2008), http:// www.federalreserve.gov/newsevents/speech/bernanke20080515a.htm (last visited Oct. 29, 2012) ("[t]he revenues of the originators of subprime mortgages were often tied to loan volume rather than to the quality of the underlying credits, which induced some originators to focus on the quantity rather than the quality of the loans being passed up the chain.”). 
Regulators could not be expected to foresee problems that were deemed unlikely by even the most expert of observers. Agency capture problems arose due, partly to powerful political interests supporting the regulated entities and, partly to competition for fees from regulated entities. $^{79}$ Thus, in a general sense, consumers were defeating disclosure statutes designed to protect them, loan originators were faced with an incentive to loosen lending standards and approve more loans, and regulators were unable to predict or correct the growing problems in consumer lending.

Further, the Gramm-Leach-Bliley (GLB) Act, ${ }^{80}$ also known as the Financial Services Modernization Act of 1999, rapidly changed market conditions in the mortgage lending industry. The Gramm-Leach-Bliley Act, which repealed part of Franklin Roosevelt's Banking Act of $1933,{ }^{81}$ more commonly known as the Glass-Steagall Act, ${ }^{82}$ was a very significant development in securities regulation. Although commentators will differ on the role the GLB Act played with respect to the financial crisis, ${ }^{83}$ the GLB Act presented a vastly changed marketplace where "firewalls" between financial institutions, in place for over sixty years, had been removed.

Existing consumer-protection based regulation undermines consumers' incentives to educate themselves with regard to the transactions at issue. Mark Armstrong recently observed the concern for moral hazard if transaction terms are restricted or consumers are allowed a remedy for improvident transactions. ${ }^{84}$ This understanding flows from the "well understood" concern that "if someone is insured, she will take less care protecting her possessions." 85 The insurance in the consumer protection story is the regulatory scheme and the possessions are the consumer's interests in the transaction terms. So "[t]he victim of a scam, or an unexpectedly high credit card penalty charge, will usually be more vigilant in the future." 86 Armstrong's moral hazard argument relies on a rational choice model of consumer behavior. ${ }^{87}$ But it holds for boundedly rational consumers as well. Evidence from empirical studies of individuals' behavior demonstrates that education and experience reduces the effect of cognitive biases. ${ }^{88}$

Lastly, consumer-protection-based regulation is inherently disempowering. An approach that outlaws substantive transaction terms, which may be appropriate for a subset of consumers, limits those consumers' abilities to choose from among the broadest possible array of available transactions. As Neil Averitt and Robert Lande argue, consumer protection laws should preserve consumers' abilities to exercise choice, while antitrust laws should preserve the existence of

\footnotetext{
${ }^{79}$ See Rachel E. Barkow, Insulating Agencies: Avoiding Capture through Institutional Design, 89 TEX. L. REv. 15, 44-45 (2010) (describing capture concerns for banking regulators based on "regulator shopping).

${ }^{80}$ Gramm-Leach-Bliley Financial Modernization Act, PL 106-102, Nov. 12, 1999, 113 Stat 1338 ("An Act To enhance competition in the financial services industry by providing a prudential framework for the affiliation of banks, securities firms, insurance companies, and other financial services providers, and for other purposes.")

${ }^{81} 12$ U.S.C. $\S 24 ; 12$ U.S.C. $\S 378(a)(1), 21(a) 1$.

${ }^{82} I d$.

${ }^{83}$ See e.g., Eric Lipton \& Stephen Labaton, A Deregulator Looks Back, Unswayed, N.Y. TIMES, Nov. 16, 2008, at A1.

${ }^{84}$ Mark Armstrong, Economic Models of Consumer Protection Policies, MPRA PAPER No. 34773, at 2-3 (Nov. 2011), available at mpra.ub.uni-muenchen.de/34773.

${ }^{85}$ Id. at 3; see also generally Steven Shavell, On Moral Hazard and Insurance, 93 Q. J. ECON. 541 (1979).

${ }^{86}$ Armstrong, supra note 84 at 4.

${ }^{87} \mathrm{Id}$. at 2.

${ }^{88}$ Cf. Gregory Mitchell, Why Law and Economics' Perfect Rationality Should Not be Behavioral Law and Economics' Equal Incompetence, 91 Geo. L.J. 67, 87-94 (2002) (education mitigates the impact of cognitive bias).
} 
choice. ${ }^{89}$ The two schemes would work at cross-purposes if consumer protection regulation were permitted to remove consumer choice.

\section{REFORMS TO MORTGAGE LENDING REGULATIONS}

Congress responded to the perceived weakness in existing regulation of the financial industry with the Dodd-Frank Wall Street Reform and Consumer Protection Act ("Dodd-Frank" Act). ${ }^{90}$ The Dodd-Frank Act revised regulation of the mortgage lending industry in the United States. ${ }^{91}$ According to Professor Pridgen, Dodd-Frank "takes a much more substantive regulatory approach than has been seen until recently in federal credit regulation." ${ }^{92}$ Reforms include new requirements that consumer borrowers' have the abilities to make payments; new limits on broker compensation models that preclude one pernicious compensation device, yieldspread-premiums; and limits on prepayment penalties, among other reforms. ${ }^{93}$

The Dodd-Frank Act has both expanded and restricted coverage of existing statutes and regulations in the mortgage lending industry. ${ }^{94}$ For instance, the Act established a new "duty of care" for residential mortgage originators. However, the "duty of care" only requires a mortgage originator: (1) to be licensed or registered as a loan originator if required by the SAFE Act ${ }^{95}$; and (2) to include the unique identifier provided by the Nationwide Mortgage Licensing System and Registry (NMLSR) on all loan documents. ${ }^{96}$

Title XIV of the Dodd-Frank Act enacted several new requirements for mortgage originators. ${ }^{97}$ Under Title XIV a loan originator is required to make a good faith and reasonable effort based upon verified information that "at the time the loan is consummated, the consumer has a reasonable ability to repay the loan." This provision may have been designed to respond to the above noted incentive for lenders to focus on the quantity of loans approved, as opposed to the quality of loans approved. However, a "qualified mortgage" will be free of many of the restrictions and limitations imposed by Title XIV on other mortgage loans, presenting the same concerns of easy avoidability that we encounter under HOEPA. ${ }^{98}$ Although the Dodd-Frank Act

\footnotetext{
${ }^{89}$ Neil W. Averitt \& Robert Lande, Using the "Consumer Choice” Approach to Antitrust Law, 74 ANTITRUST L.J. 175,181 (2007).

${ }^{90}$ The Dodd-Frank Wall Street Reform and Consumer Protection Act, P.L. 111-203 July 21, 2010, 124 Stat. 1376.

${ }^{91}$ Robert A. Cook and Meghan Musselman, Summary of the Mortgage Lending Provisions in the Dodd-Frank Wall Street Reform and Consumer Protection Act, 64 CONSUMER Fin. L.Q. ReP. 231 (Summer/Fall, 2010).

${ }_{92}$ Dee Pridgen, Putting Some Teeth in TILA: From Disclosure to Substantive Regulation in the Mortgage Reform and Anti-Predatory Lending Act of 2010, 24 LOY. CONS. L. REV. 615, 616 (2012).

${ }^{93}$ See id. at $627-28$ (citing 15 U.S.C. $1639 \mathrm{c}$ ).

${ }^{94} \mathrm{See} i d$. for a greater discussion of the impact of the Dodd-Frank Act on mortgage lending regulation in which the authors detail Dodd-Frank's expanded HOEPA coverage, new mortgage originator rules, increased penalties, new disclosure burdens, and new escrow and force-placed insurance rules, among other reforms.

${ }^{95}$ Secure and Fair Enforcement for Mortgage Licensing Act of 2008 ("SAFE Act"), 12 U.S.C. § 5100, et seq.

${ }^{96}$ See, e.g., Cook and Musselman, supra note 91; the authors note, "By placing this duty in TILA, the Dodd-Frank Act allows the TILA penalties to be imposed on a mortgage originator for a failure to comply with these rules." See also id.

${ }^{97}$ Dodd- Frank Act, infra, note 98.

${ }^{98}$ Dodd-Frank Act $§ 1491$; A "qualified mortgage" is defined as a mortgage loan "(i) that does not allow for negative amortization and is not a balloon loan, (ii) for which the creditor verifies and documents the borrower's income and assets, (iii) that is underwritten using a fully-amortizing payment schedule (for an ARM loan, underwritten based on the maximum rate permitted during the first five years of the loan term) taking into account all applicable taxes, insurance and assessments, (iv) for which total points and fees do not exceed $3 \%$ of the total loan amount, and (v) that complies with debt-to-income ratios established by the Federal Reserve Board." DoddFrank Act § 1411; see Robert M. Jaworski, Jaworski on the Mortgage Reform and Anti-Predatory Lending Act, 2010 LeXISNeXIS EMERGING ISSUES 5346 (Oct. 6, 2010).
} 
provides a new enforcement role for the FTC with respect to home appraisals, ${ }^{99}$ and has increased penalties for violations of TILA, ${ }^{100}$ the reforms do not promise to negate the justification for resort to antitrust law and policy into this area.

Dodd-Frank's effectiveness has yet to be determined. "The Dodd-Frank Act may have a significantly greater [or lesser] effect depending on how the new Bureau of Consumer Financial Protection ["CFPB"] exercises its considerable powers."101 In late January 2013 the CFPB took a substantial step, promulgating seven rules pertaining to mortgage lending. The new rules impact statutes that are mainstays of mortgage regulation, such as TILA and RESPA. ${ }^{102}$ Many of these new rules will go into effect on June 1, 2013, and the last of the rules will go into effect in January $2014 .^{103}$

One notable example is the agency's ability to repay (“ATR") and qualified mortgage ("QM") standards rule. That requires "mortgage lenders to consider consumers' ability to repay home loans before extending them credit."104 At a minimum, "creditors will be required to consider eight underwriting factors: (1) current or reasonably expected income or assets; (2) current employment status; (3) the monthly payment on the covered transaction; (4) the monthly payment on any simultaneous loan; (5) the monthly payment for mortgage-related obligations; (6) current debt obligations, alimony, and child support; (7) the monthly debt-to-income ratio or residual income; and (8) credit history."105 In addition, creditors will be required to use "reasonably reliable third-party records to verify the information they use to evaluate the factors." 106

The second part of the rule deals with "qualified mortgages." The Dodd-Frank Act provides that a creditor that extends a "qualified mortgage" presumptively satisfied the ability-torepay requirements. Here, "[ $\mathrm{t}]$ he line the $[\mathrm{CFPB}]$ is drawing is one that has long been recognized as a rule of thumb to separate prime loans from subprime loans."107 In addition, the CFPB

\footnotetext{
${ }^{99}$ Dodd-Frank Act, supra note 98.

100 "TILA penalties have been increased as follows: the class action liability cap is raised to $\$ 1,000,000$; mortgage originators are subject to TILA penalties for compensation and steering violations; the heaviest penalties (by far) are applied to violations of the rules related to appraisal independence; and state attorney general enforcement is expanded." Id.

${ }^{101}$ Cook \& Musselman, supra note 91 at "Summary".

102 TILA-related rules: Loan originator compensation requirements, mortgage servicing requirements, high-cost mortgage and homeownership counseling amendments, escrow requirements for higher-priced mortgages, and ability to repay and qualified mortgage standards; RESPA-related rules: homeownership counseling amendments, and mortgage servicing requirements (See Proposed Rules Bureau of Consumer Financial Protection, High-Cost Mortgage and Homeownership Counseling Amendments to the Truth in Lending Act (Regulation Z) and Homeownership Counseling Amendments to the Real Estate Settlement Procedures Act (Regulation X), 78 FR 6856-01 (Jan. 31, 2013)); ECOA-related rules: disclosure and delivery requirements for copies of appraisals and other written valuations (See Proposed Rules Bureau of Consumer Financial Protection, Disclosure and Delivery Requirements for Copies of Appraisals and Other Written Valuations Under the Equal Credit Opportunity Act (Regulation B), 78 FR 7216-01 (Jan. 31, 2013).

103 See CFPB, Ability to Repay Summary, cfpb.com; available at: http://www.consumerfinance.gov/regulations/ ability-to-repay-and-qualified-mortgage-standards-under-the-truth-in-lending-act-regulation-z/ (last accessed: Feb. 10, 2013).

${ }^{104}$ See id.

${ }_{105}$ See id.

${ }^{106}$ See id.

107 See CFPB, Ability to Repay Summary, cfpb.com; available at: http://www.consumerfinance.gov/regulations/ ability-to-repay-and-qualified-mortgage-standards-under-the-truth-in-lending-act-regulation-z/ (last accessed: Feb. 10, 2013).
} 
exempted smaller creditors from certain provisions because "[t]he [CFPB] believes that the discipline imposed when small creditors make loans that they will hold in their portfolio is sufficient to protect consumers' interests in this regard."108

\section{A ROLE FOR ANTITRUST LAW}

The limitations of targeted regulation in preventing a harmful spiral in which harmful conduct leads to market structure characterized by dominance or market leadership, which in turn facilitates harmful conduct, suggests that legal protections must not rely on foresight on the part of regulators; must not rely on whack-a-mole responses to problems as they appear; must be structured to limit concerns for agency capture by regulated entities; must not limit consumer choice; and must not present moral hazard concerns. ${ }^{109}$

Antitrust offers a quiver of legal protections that satisfy those requirements. Broad private rights of action create incentives for consumers or competitors to bring suit, mitigating the problem of limited regulator foresight into the long-term consequences of a course of bad conduct. Private plaintiffs are likely to be better informed about the actual or threatened market effects of an observed course of conduct because they themselves participate in the market. Private plaintiffs also have financial incentives to seek both injunctive and monetary relief before possible extra-market consequences of the conduct are realized.

Second-order regulation, like antitrust, mitigates agency capture concerns. The decisionmakers - courts - are diffuse, unelected and life-tenured (in the federal system), and subject to appellate review. Federal enforcement agencies will not be free from capture concerns. But those concerns are mitigated in antitrust because the agencies are themselves generalists; the two federal agencies compete between themselves - and with state enforcers - in their enforcement programs; and private enforcement remains a check on public enforcers' abdication of their role.

\section{A. BeHAVIORAL ExPloitATION As BAD ANTITRUST CONDUCT}

The antitrust approach to behavioral exploitation operates by treating behavioral exploitation as conduct of concern under the antitrust laws. A plaintiff can challenge behavioral exploitation with a showing of general intent and a market effect, giving rise to antitrust remedies including injunctive relief and treble damages liability. Our approach differs from toobig-to-fail approaches because we do not advocate challenges on the basis of market structure, which can be achieved through innocent and even efficient conduct. Our approach differs from the status quo of antitrust doctrine because we expand the class of conduct that will be seen to raise concerns.

There are three broad categories of antitrust analysis under the modern state of doctrine. First is dominant firm conduct, whereby a firm engages in conduct of concern and in doing so creates, threatens to create, or preserves a monopoly position. ${ }^{110}$ Remedies are available under Section 2 of the Sherman Act on a showing of both market power (dominance) and bad conduct. ${ }^{111}$ Second is concerted conduct, whereby more than one firm agrees jointly to engage in a course of conduct of concern. ${ }^{112}$ Remedies are available under Section 1 on a showing of

108 Proposed Rules Bureau of Consumer Financial Protection, Ability To Repay Standards Under the Truth in Lending Act (Regulation Z), 78 FR 6622-01 (Jan. 30, 2013).

${ }^{109}$ See supra Part II.F (describing the failings of the regulatory status quo).

110 See Mark Anderson \& Max Huffman, Iqbal, Twombly, and the Expected Cost of False Positive Error, 20 CORNEll J. L. \& PuB. POL'y 1, 41 (2010).

${ }^{111} 15$ U.S.C. $\S 2$.

${ }^{112}$ See Anderson et al., supra note 110, at 29. 
agreement and bad conduct. ${ }^{113}$ Third is merger review, whereby firms seek to combine to create a single firm, and after the combination the market structure will facilitate harmful conduct. ${ }^{114}$

All three categories of analysis rely on a showing of harmful conduct. It is subject to interpretation and common-law what exactly constitutes such harmful conduct. ${ }^{115}$ Liability for monopolistic activity requires proof of both market power and harmful conduct. ${ }^{116}$ Liability for concerted activity requires proof of agreement and harmful conduct. ${ }^{117}$ Merger review requires proof of actual or likely harmful effects from the merger, which turns on increased incentive and opportunity to engage in either unilateral or concerted harmful conduct. ${ }^{18}$ A relatively noncontroversial definition of harmful conduct would require the threat of market-wide harm and the possibility of regulation without unduly restricting economically desirable activity. ${ }^{119}$

Behavioral exploitation antitrust is a new approach that one commentator has recently described in detail ${ }^{120}$ and other commentators are beginning to accept. None of the examples of harmful conduct that have presented bases for antitrust liability are easily analogous to behavioral exploitation. The most likely extension of current doctrine would be a creative application of the theory of predatory pricing. Predatory pricing occurs when a firm prices its product or service below the firm's costs to provide the product or service. ${ }^{121}$ In understanding the subprime boom as a series of improvident loan transactions that were cheap relative to their risks (a component of lender cost structure), we might find an example of below-cost pricing. ${ }^{122}$

Maurice Stucke has suggested a comparable expansion of the malleable definition of harmful antitrust conduct for deception that brings about market effects. Recognizing that deceptive conduct lacks any redeeming characteristics and presents real competitive dangers, Stucke argued for application of antitrust's "quick look" standard to reviewing deceptive conduct, shifting the burden of proof to the defendant to demonstrate a lack of harm once the conduct is proved. ${ }^{123}$ Behavioral exploitation has a stronger claim than deception to antitrust remedies. Existing regulation at both the federal and state levels prohibits and remedies deception, including in consumer subprime mortgage lending. ${ }^{124}$ In contrast, behavioral

\footnotetext{
11315 U.S.C. $\S 1$.

11415 U.S.C. $\S 18(\mathrm{a})$.

115 See, e.g., Competition and Monopoly: Single Firm Conduct Under Section Two of the Sherman Act $\S 1$ (2008) (report withdrawn) (noting that bad conduct for Section 2 purposes is "willful acquisition or maintenance of monopoly power" as opposed to "growth or development as a consequence of a superior product, business acumen, or historic accident") (quoting Grinnell).

116 See Anderson et al., supra, note 110.

117 See id. at 30.

${ }^{118}$ U.S. Dep't of Justice \& Federal Trade Comm'n, Horizontal Merger Guidelines $\S \S 6,7$ (2010).

119 This first principles understanding of what constitutes bad conduct invokes the complex question of optimal deterrence. See generally Daniel A. Crane, The Economics of Antitrust Enforcement, in ANTITRUST LAW \& ECONOMICS 1, 3-5 (Keith N. Hylton, ed., 2010). Trusting that, as Crane observes id. at 4, there are ample forces at play seeking to undermine existing, and limit innovation in the development of, antitrust liability rules, we leave it to others to articulate the over deterrence argument.

${ }^{120}$ Huffman, supra note 11 , at 130-35.

${ }^{121}$ Brooke Group v. Brown \& Williamson Tobacco Co., 509 U.S. 209 (1993).

${ }^{122}$ See id at 9-17, ("below an appropriate measure of cost"). Brooke Group also requires a dangerous probability of recoupment of the losses incurred during the course of predation. Recoupment ordinarily is found when a firm achieves a durable monopoly position. A plaintiff might be able to establish the dangerous probability of recoupment over the course of a borrower's long-term relationship with the lender. Scholarship does not discuss "below-cost lending," although the idea certainly emerges in the context of political benefits or kickbacks.

${ }^{123}$ See id. at $11,13-19$.

${ }^{124}$ See, e.g., Truth in Lending Act, 15 U.S.C. 1601 et seq.; Federal Trade Commission Act, 15 U.S.C. § 45.
} 
exploitation is regulated only at the margins. Applying an antitrust remedy for behavioral exploitation does not threaten the same level of redundancy.

Applying behavioral exploitation antitrust to the consumer subprime mortgage marketplace, we propose that behavioral exploitation meets the conduct element of a claim under Sherman Act section 1 or 2 or merger review under Clayton Act section $7 .^{125}$ Considering briefly the state of the consumer subprime mortgage marketplace leading up to 2007, we conclude that behavioral exploitation antitrust fits most naturally with merger review; might be (with some doctrinal adjustment) an appropriate fit with a challenge to concerted action under section 1; and is unlikely to inform a challenge to dominant firm conduct under section 2 . We order the following sections in order of most to least appropriate fit.

\section{BEHAVIORAL EXPLOITATION ANTITRUST IN MERGER REVIEW}

Injunctive and damages remedies under Clayton Act, section 7, and FTC Act, section 5, (injunction only) for a merger that "tends to create a monopoly" arises where the merger increases the incentive and opportunity for a firm to engage in conduct of concern. ${ }^{126}$ The merger theory will be the simplest application of behavioral exploitation antitrust in an industry characterized by mergers with substantial increases in concentration.

Merger enforcement under the Clayton Act does not require proof of harmful conduct, in contrast with the dominant firm conduct and concerted conduct we discuss above. The recently revised Merger Guidelines recognize increased opportunity and incentive to raise prices to be an effect that provides a basis for blocking a merger, ${ }^{127}$ although raising prices in isolation is conduct that benefits competition by incentivizing market entry. ${ }^{128}$ Similarly, increased likelihood of tacit collusion provides a basis for blocking a merger, ${ }^{129}$ although the tacit collusion itself, under the current state of the law, is not illegal. ${ }^{130}$ In both cases the competitive harm is in the merger itself rather than in the conduct that it allows.

A successful merger challenge usually requires proof of an increase in concentration sufficient to have a market effect. ${ }^{131}$ Merger review in a market such as that for consumer subprime mortgage lending under behavioral exploitation antitrust would not change that requirement. A merger between two firms engaged in behavioral exploitation, or in which the acquiring firm engages in behavioral exploitation, can be expected to increase the incidence of that conduct in the market. In either circumstance the merger limits competitive constraints that may exist on its continuing - i.e., there is one fewer firm that might find it advantageous to stop and to educate consumers as to the existence of the conduct. ${ }^{132}$

Increased concentration also increases the likelihood of tacitly collusive behavioral exploitation. Tacit collusion occurs when competitors act in coordinated fashion rather than competing, but do so without the agreement necessary to bring about a section 1 violation for conspiring. One market structure characteristic that increases the likelihood of tacit collusion is

\footnotetext{
125 See U.S. Dep't of Justice \& Fed. Trade Comm'n, Horizontal Merger Guidelines $\S \S 6,7$ (2010) (discussing unilateral and coordinated effects in merger review) [hereinafter "Merger Guidelines"].

${ }^{126}$ See id. at $\S 1$ (noting concerns for incipient price increases, output reductions, reductions in innovation, or other "diminished competitive constraints or incentives").

127 See Merger Guidelines, supra note 125, at $\S 6.3$.

${ }^{128}$ See Merger Guidelines, supra note 125 at $\S 9.2$.

129 See Merger Guidelines, supra note 125, at $\S 7$.

${ }^{130}$ See supra, section II.B.1.

${ }^{131}$ Cf. Merger Guidelines, supra note 125, at $\S 2.1 .3$ (increases in concentration "presumed to be likely to enhance market power").

${ }^{132}$ We discuss infra our view that this competitive effect is unlikely in any event.
} 
concentration. Where a merger brings about increased concentration, which increases the likelihood of tacitly collusive behavioral exploitation, that merger creates an incipient harm that may be sufficient to permit antitrust remedies.

\section{BEHAVIORAL EXPLOITATION ANTITRUST IN A CONCERTED ACTION CHALLENGE}

Sherman Act section 1 provides a basis for competitors, government enforcers and consumers to challenge groups of firms who act by agreement. Concerted conduct requires proof of two elements: agreement and conduct. Under behavioral exploitation antitrust, engaging in behavioral exploitation with general intent, producing a market effect, meets the conduct element. Antitrust remedies should be available on proof of agreement.

We do not know of evidence that mortgage lenders actually conspired, whether explicitly or implicitly, with regard to transaction terms or marketing tactics employed in consumer subprime mortgage lending in the years leading to the financial crisis. Instead, the market appears to have been vigorously competitive. Proving the existence of an agreement would require relying on evidence of tacit collusion, by which lenders achieved de facto consensus through a course of interdependent conduct.

Faced with behaviorally exploitative conduct by a competitor, a firm may compete by itself, eschewing the conduct and advertising its knowledge of its competitor's actions. The firm also may find it profitable to engage in the same conduct itself. Evidence of industry-wide behavioral exploitation in consumer home mortgages suggests firms found the latter option more appealing. The welfare effect is the same as if the competitors had colluded. In the absence of a merger review proceeding, section 1 and FTC Act section 5 are the most frequently cited sources of authority for challenging tacitly collusive harmful conduct.

The law is clear that tacit collusion based on interdependent conduct does not amount to an agreement cognizable under section $1 .{ }^{133}$ There have been calls to broaden the definition of agreement to include tacit collusion. Richard Posner argued in 1969 that there is no economic distinction between tacit and actual collusion. Both present the same welfare effects and should be outlawed. ${ }^{134}$ Some have suggested a middle ground, outlawing tacit collusion under the broader language of FTC Act section 5 but not under section 1. ${ }^{135}$ The middle-ground approach has the perceived benefit of preventing excessive litigation by private plaintiffs, who have standing to enforce the Sherman Act but not the FTC Act. ${ }^{136}$

We advocate an expansive enforcement program for tacitly collusive behavioral exploitation in consumer subprime mortgage lending. Consumer subprime mortgage lending has proved to be subject to enduring "lemons equilibria," where sub-optimal transaction terms push out welfare maximizing terms. ${ }^{137}$ The benefits of antitrust enforcement under section 1 or FTC

\footnotetext{
${ }^{133}$ See Bell Atlantic Corp. v. Twombly, 550 U.S. 554 (2007); Max Huffman, The Necessity of Pleading Elements in Private Antitrust Conspiracy Claims, 10 U. PA. J. Bus. \& EMP. L. 627 (2008).

${ }^{134}$ Richard Posner, Natural Monopoly and its Regulation, 21 STANFORD L. ReV. 548 (1969); see also Posner, ANTITRUST LAW (2d ed. 2001).

${ }^{135}$ See Donald F. Turner, The Definition of Agreement Under the Sherman Act: Conscious Parallelism and Refusals to Deal, 76 Harv. L. Rev. 655, 682 (1962).

${ }^{136}$ See Thomas B. Leary, A Suggestion for the Revival of Section 5, Antitrust Source, Feb. 2009, at 1, 1-3. But see William E. Kovacic \& Mark Winerman, Competition Policy and the Application of Section 5 of the Federal Trade Commission Act, 76 AnTITRUST L.J. 929, 939 \& n.54, 948 \& n.84 (2010) (noting that Section 5 standards may be used to interpret state laws that do allow for private enforcement, and that Section 5 holdings may serve as precedent in later private litigation).

${ }^{137}$ For an application of the theory of lemons equilibria to consumer home mortgage lending, see Janger \& BlockLieb, supra note 13.
} 
Act section 5 outweigh the harms from over-enforcement. We believe it is possible to limit an expanded enforcement program targeting tacit collusion to markets with characteristics like that for consumer subprime mortgage lending. Under our middle-ground approach, tacitly collusive conduct in consumer lending would provide a basis for both private and public enforcers to sue seeking damages and injunctive relief.

\section{BEHAVIORAL EXPLOITATION ANTITRUST IN A DOMINANT FiRM CONDUCT CHALLENGE}

Proof of dominant firm conduct in violation of Sherman Act section 2 requires proof of both monopoly power (or a dangerous probability of achieving it) and bad conduct. Section 2 presents the simplest example of an enforcement theory relying on behavioral exploitation. The claim works this way: A plaintiff, probably a competitor, sues Countrywide Financial in 2006. That competitor may be Wells Fargo, which testified to the Financial Crisis Inquiry Commission that it lost money by refusing to engage in the most extreme forms of subprime lending. The plaintiff would argue that Countrywide was on its way to achieving market dominance because it acted with intent in exploiting consumer biases, inducing them to enter into transactions that are suboptimal. The result is that the plaintiff is prevented from lending to those same consumers presumably making smaller loans, but ones that are more consistent with the consumer's abilities to pay - the phenomenon of bad loans crowding out good loans or even wholly different types of lending (e.g., student loans). The competitor's remedy would treble the hypothetical profit on the loans that were lost to the competitor plaintiff competitor, as well as injunctive relief to prevent the defendant from engaging in the conduct in future transactions.

Government enforcers might also bring enforcement actions seeking injunctive relief against further behavioral exploitation. In an extreme case, the government enforcer might seek a structural remedy to reduce the size of the dominant firm. ${ }^{138}$ Consumer enforcement is hypothetically available, but is not realistic. It is difficult to envision a basis for monetary relief to consumers, and consumers lack incentives to finance a lawsuit seeking injunctive relief.

Available evidence does not suggest that any firm achieved sufficient market presence to meet the standards for dominance required by section 2 . In a nation- or world-wide market for financial products with ease of entry and exit into mortgage lending, it seems unlikely market dominance or the dangerous probability of its occurring, as section 2 requires, might ever be achieved.

\section{B. Antitrust Avoids the Problems with the Leading Approaches to Consumer} Mortgage REgulation

The problems with consumer-protection style regulation that we detail in Part II, above, demonstrate the need for legal protections (1) that do not depend on regulator foresight, (2) that do not present concerns for agency capture, (3) are not whack-a-mole in nature, and (4) do not present consumer choice or moral hazard concerns. Antitrust enforcement meets those requirements.

1. COMPETItion FOR ENFORCEMENT Mitigates PROBLEMS OF No FOREsight aND AGENCY CAPTURE

U.S. antitrust is known for its "decentralized and largely uncoordinated" enforcement mechanisms. ${ }^{139}$ Those include enforcement by two federal agencies - the Department of Justice and the Federal Trade Commission; ${ }^{140}$ federal "sectoral" regulators with public interest

\footnotetext{
${ }^{138}$ Cf. United States v. Microsoft, 87 F. Supp. 2d 30 (DDC 2000) (providing for a structural remedy).

${ }^{139}$ Crane, Economics of Enforcement, supra note 119, at 1.

${ }^{140}$ See 15 U.S.C. $\S 4$ (DOJ); 15 U.S.C. $\$ 45$ (FTC).
} 
mandates, which frequently include competition policy enforcement; ${ }^{141}$ enforcement of both federal and state law by state attorneys general; ${ }^{142}$ and enforcement by private plaintiffs. ${ }^{143}$ The procedural mechanisms and remedies available to the various enforcers differ as well, creating what one commentator calls a "crazy quilt of enforcement mechanisms."144

Antitrust does not rely on neutral or foresighted regulators. The competitive, belts and suspenders form of antitrust enforcement mitigates both of these concerns. One result of the diffuse nature of U.S. antitrust enforcement is the competition for enforcement that it produces. ${ }^{145}$ "As an independent agency, the FTC is perhaps less quickly responsive to external political forces than the Antitrust Division."146 Another benefit of overlapping enforcement authority is that we have many sets of eyes on potential problems. Where government enforcers are blind to something, consumers and competitors may see them. Where consumers and competitors know too little, government enforcers have enhanced fact-finding powers. ${ }^{147}$ So it is less likely something slips by.

The role of state attorney general and private plaintiff enforcement both in supporting federal government antitrust enforcement and in filling gaps left by federal government inactivity also has been recognized. ${ }^{148}$ A ready example of state attorney general activity is the continued pursuit of Microsoft Corporation by state enforcers after the Justice Department settled its claim. $^{149}$ A similar situation occurred when state enforcers continued to challenge the CNBC/Financial News Network merger in bankruptcy court in $1991 .^{150}$

${ }^{141}$ See, e.g., Jonathan B. Baker, Sector Specific Competition Enforcement at the FCC 1 (Sept. 21, 2010) ("sectorspecific enforcement by the FCC complements generalist competition enforcement to the benefit of competition in the communications industry"), available at transition.fcc.gov/osp/projects/baker-enforcement-091210.pdf; Henry L. Thaggert, Antitrust \& Public Procurement, 7 COMP. L. INT'L 82, 84 n.30 (2011) (noting the role of the General Accounting Office in ensuring competitive conditions in government contracting).

${ }^{142}$ See 15 U.S.C. $\S 15$ c (state enforcement of federal law); see, e.g., N.Y. Gen. Bus. L. $§ 340$ et seq. (New York State antitrust law).

${ }^{143} 15$ U.S.C. $\$ 15$.

${ }^{144}$ Crane, Economics of Enforcement, supra note 119, at 1.

145 See James J. Park, Rules, Principles, and the Competition to Enforce the Securities Laws, 100 CAL. L. REV. 115 (2012) ("A number of commentators contend that decentralized enforcement leads to competition by enforcers that checks underenforcement."). Id. at n.52 ("The idea that enforcement is optimized through competition between enforcers has been made in other contexts. See, e.g., Richard S. Higgins et al., Dual Enforcement of the Antitrust Laws, in PUBlic ChOICE \& REgulation 154 (Robert J. Mackay et al. eds., 1987) (concluding that competition among enforcers leads to efficient enforcement); Gary S. Becker \& George S. Stigler, Law Enforcement, Malfeasance, and Compensation of Enforcers, 3 J. LEGAL STUD. 1, 14 (1974) (observing that enforcers could compete);

William E. Kovacic, Procurement Reform and the Choice of Forum in Bid Protest Disputes, 9 ADMIN. L.J. OF AM. U. 461, 493 (1995) ("Federal antitrust enforcement authority is shared by the Department of Justice and the Federal Trade Commission (FTC), and these two agencies compete to establish preeminence as the leading government bureau for the scrutiny of many forms of business conduct, including mergers."). Cf. Spencer W. Waller, Prosecution by Regulation: The Changing Nature of Antitrust Enforcement, 77 OR. L. REV. 1383, 1418 (1998) (noting the competing agency phenomenon).

${ }^{146}$ Daniel A. Crane, Does Monopoly Broth Make Bad Soup?, 76 AnTITRUST L.J. 663 (2010).

${ }^{147}$ See, e.g., 15 U.S.C. $§ 46$ (FTC's general investigatory powers).

148 DAniel A. Crane, The Institutional Structure of Antitrust Enforcement 145 (Oxford University Press 2011) (noting the "power of states to be more aggressive in antitrust enforcement than the federal government"); $i d$. at 163 ("private enforcement of the antitrust laws vastly outstrips public enforcement").

${ }^{149}$ See New York v. Microsoft Corp., 297 F. Supp. 2d 15, 19-20 (D.D.C. 2003).

${ }^{150}$ See Pennsylvania Attacks Award of FNN to CNBC, 60 ANTITRUST \& TRADE REG. REP. (BNA) 698,699 (1991). 
Private plaintiff enforcement by both consumers and competitors also complements or replaces federal government enforcement. For example, Bell Atlantic Corp. v. Twombly was a private action brought by consumers after the Department of Justice closed its investigation and declined to pursue the alleged conduct. ${ }^{151}$ Consumer plaintiffs sued over conduct conducted as part of a joint venture between Shell Oil Company and Texaco Inc. after the FTC had approved the joint venture. ${ }^{152}$ Competitor Sprint Corporation brought its own complaint challenging the AT\&T/T-Mobile merger, in what one news outlet reported as a supplement to the Justice Department's suit. ${ }^{153}$

Strong financial and/or competitive incentives exist for private plaintiffs to bring antitrust claims. $^{154}$ Those incentives increase the likelihood of aggressive regulation by antitrust enforcement, which promises to fill the gaps in regulation in the pre-crisis status quo. Importantly, the incentives operate independently of foresight about extra-market, economywide harms, so private plaintiffs can be relied on to use their antitrust enforcement authority when extra-market harms are not otherwise observable. ${ }^{155}$ Private enforcement offers another benefit. Knowledgeable consumers and competitors are the plaintiffs best situated to understand the potential harm from a course of behavioral exploitation. They are likely to be more nimble in responding to the conduct than would be public enforcers.

The unique structure of antitrust enforcement also substantially mitigates concerns for agency capture. ${ }^{156}$ That is for at least three reasons: First, unlike the banking regulators discussed above, the antitrust enforcement agencies are not closely tied to any one industry. ${ }^{157}$ Second, the FTC has a bipartisan structure, which Rachel Barkow notes offers the promise of unbiased decisions. ${ }^{158}$ Third, competition for enforcement acts as a check on inactivity by any one enforcing entity. Tim $\mathrm{Wu}$ observes the lesser public choice concerns with antitrust enforcement vis-à-vis one sectoral regulator (the FCC), noting that deferring to regulators over antitrust "ignores the public choice problems that can make alternatives to antitrust ineffective . . . . A strong firm can overpower an agency, which is why I think the antitrust law must always be around as a backup."159

\section{ANTITRUST'S RULE OF REASON AVOIDS WHACK-A-MOLE REGULATION}

The story of consumer protection-based regulation in the consumer mortgage industry has not been a happy one. The regulation is insufficient to cure all potential problems. Congress

${ }^{151}$ See 550 U.S. 544 (2007).

${ }_{153}^{152}$ See Texaco Inc. v. Dagher, 547 U.S. 1 (2006).

${ }^{153}$ See Tom Schoenberg et al., Sprint Allowed to Pursue Legal Challenge to AT\&T-T-Mobile Deal, BLoomBURG, Nov. 3, 2011, available at bloomberg.com/news/2011-11-02/at-t-loses-bid-to-dismiss-sprint-s-antitrust-challengeto-t-mobile-deal.html.

${ }^{154}$ See Max Huffman, A Standing Framework for Private Extraterritorial Antitrust Enforcement, 60 SMU L. REV. 103, 114 (2007) (private plaintiffs are "motivated solely by their individual best interests").

${ }^{155}$ By contrast, prescient regulators who sought to act during a time of economic expansion risked being labeled Henny Pennys.

156 But see Daniel Crane, Rethinking Merger Efficiencies, 110 U. Mich. L. REV. 347, 379 (2011) ("Public choice literature suggests that antitrust enforcers are not merely detached public servants on a truth-seeking expedition.") (citing The Causes and Consequences of Antitrust: The Public Choice Perspective (Fred S. McChesney \& William F. Shughart II eds., 1995) (discussing the application of public choice theory to antitrust enforcement)).

${ }^{157}$ Commentators note that overrepresentation of any one industry presents the greatest single basis for capture concerns. Rachel E. Barkow, Insulating Agencies: Avoiding Capture through Institutional Design, 89 TEX. L. REV. $15,22(2010)$.

${ }^{158}$ Id. at 21 .

${ }^{159}$ Interview with Tim Wu, FTC Policy Advisor, 25 Antitrust 55, 57 (Summer 2011). 
has tended to regulate in reaction to perceived existing problems, rather than proactively ward off incipient ones. It is also subject to arbitrage, opening new opportunities for deceptive or behaviorally exploitative conduct. Short of onerous regulation of substantive transaction terms that would have the effect of foreclosing access to the market to both marginal lenders and marginal borrowers, consumer protection regulation cannot escape the problems of narrowness, reactivity, and opportunity for arbitrage.

Antitrust's rule of reason avoids whack a mole ${ }^{160}$ regulation. The rule of reason is the regulatory version of a very large tent, directing courts to consider a "broad range of factors" in deciding whether conduct is harmful (and therefore an antitrust violation) or is not. ${ }^{161}$ It is a "fact-intensive" inquiry. ${ }^{162}$ Conduct with harmful welfare effects that exceed the benefits by a sufficient margin to warrant the expense of investigation and prosecution potentially is subject to antitrust challenge. That malleable definition is broad enough to encompass the behavioral exploitation conduct that we discuss here. ${ }^{163}$

\section{Consumers Retain Choice and Are Not Subject to Moral Hazard Concerns}

Two benefits of the behavioral exploitation antitrust approach to mortgage lending regulation flow from the nature of the antitrust remedy. Antitrust enforcement targets marketwide conduct and effects rather than transaction-level conduct and effects, mitigating concerns that (1) less-efficient competitors might use regulation and litigation to protect themselves against their efficient rivals, and (2) consumers use regulation and litigation to avoid the consequences of improvident decisions.

A major failing of consumer-protection-based regulatory schemes is the regulatory removal of consumer choice. ${ }^{164}$ In this sense, mortgage lending is no different from selling widgets: regulation that prescribes the dimensions of a widget prevents a consumer from satisfying a different want or need by purchasing a widget of a different size. If we assume nearly infinite variability in ideal transaction terms (not an extreme assumption in a market with millions of transactions entered yearly), regulation that prohibits or limits access to any contract terms necessarily prevents some would-be contracting parties from maximizing their utility. ${ }^{165}$

The emphasis in the Dodd-Frank Act on protecting consumers by limiting opportunities to engage in certain mortgage transactions raises the concern for limited choice. Even the most potentially abusive of transaction terms present economically rational options for some customers. For one example, an "option ARM" is a form of subprime mortgage transaction frequently touted as abusive because it couples a low introductory interest rate with interest-only

\footnotetext{
${ }^{160}$ Whack-a-mole is an arcade game in which the player's objective is to hit representations of moles with a padded mallet. The moles re-emerge randomly from a set of holes, and the game is designed such that is impossible to suppress all of the moles for any period of time. http://en.wikipedia.org/wiki/Whac-A-Mole.

${ }^{161}$ Edward D. Cavanagh, The Rule of Reason Re-Examined, 67 Bus. LAW. 435, 435 (2012) (criticizing the openended and ambiguous nature of the rule of reason).

${ }^{162} I d$. at 436.

${ }^{163}$ The open-ended nature of the rule of reason inquiry has its down-sides as well. See Cavanagh, supra note 161, at 265 (Because the targeted regulatory alternative has been so demonstrably insufficient, we favor the open-ended and ambiguous rule of reason.).

${ }^{164}$ See Timothy J. Muris, The Benefits, and Potential Costs, of FTC-Style Regulation in Protecting Consumers, 8 COMP. L. INT'L 11, 14 (2012) (consumer protection programs may limit sellers' abilities to offer what consumers demand).

${ }^{165}$ Innovation in mortgage products became permissible in the 1980s when federal legislation recognized the problems of state laws that limited consumer choice by restricting consumers to narrow parameters for transaction terms. See Mclean \& Nocera, All the Devils are Here: The Hidden History of the Financial Crisis 29 (discussing the Alternative Mortgage Transaction Parity Act of 1982).
} 
or minimum payment requirements. ${ }^{166}$ Under Dodd-Frank, the option ARM is considered a "non-qualified mortgage," 167 a status that limits the ability of and incentives for brokers to make the lending product available to consumers. But it is not difficult to envision an appropriate customer for such a mortgage: a borrower faced with a known large future income stream perhaps a college football player who has been drafted in the first round, or a trust beneficiary who stands to access the corpus of the trust at a known point in time.

Antitrust enforcement based on behavioral exploitation does not suffer the failing of limiting consumer choice. As a second-order regulatory scheme, antitrust almost never prohibits conduct without demonstrated effects (only when rules of per se illegality apply). ${ }^{168}$ Behavioral exploitation offers a remedy only upon proof of a market effect. Lenders retain broad discretion to negotiate transaction terms that meet consumer demand. It is possible, of course, that lenders will shy away from transaction terms that do not represent industry standards because of a perceived danger of antitrust liability, creating a chilling effect on innovation in mortgage markets. We limit or eliminate that chilling effect with our requirement of a market effect for behavioral exploitation antitrust. Antitrust remedies will be available only where that discretion is abused in a sufficiently broad range of cases to have a non de minimis market effect.

Consumer protection regulation presents moral hazard concerns by freeing consumers from the consequences of their decisions. ${ }^{169}$ That concern is not present in the application of behavioral exploitation antitrust to consumer subprime mortgages for two reasons. First, the repeat player circumstance is infrequent in the context of mortgage transactions, and perhaps even less frequent for subprime mortgages. Consumers do not complete such transactions frequently enough to become conditioned by over availability of remedies. Second, a single consumer with buyer's remorse does not meet the requirement of a market effect. Only across a large number of transactions, can the market effects be found.

\section{THE Limits of BeHAVIORAL EXPLOITATION ANTITRUST}

We are cognizant of the dominant modern view that innovation in theories of antitrust harm, like the theory we propose, must be justified in terms of the cost of regulation balanced against the cost of not regulating. ${ }^{170}$ But we also do not ignore that courts, enforcers, and commentators have largely internalized the concern regarding over-enforcement, or false positives, that the dominant strain of antitrust thought succeeded in advancing in the 1970s and 1980s. ${ }^{171}$ Behavioral exploitation antitrust is an innovative theory of enforcement that promises to help to rein in otherwise difficult-to-regulate conduct that is well understood to bring about negative welfare effects. If applied in the consumer subprime mortgage industry, behavioral exploitation antitrust promises to mitigate an under-enforcing status quo.

166 See Option Adjustable-rate Mortgage - Option ARM, INVESTOPEDIA, (May 10, 2012) http://www.investopedia.com/terms/o/option_ARM.asp\#axzz1uUMXUubZ.

${ }^{167}$ See 15 U.S.C. $\$ 1639$ C(b)(2)(A) (listing criteria for a mortgage loan to be a qualified mortgage).

${ }^{168}$ Per se illegality is reserved for a narrow class of conduct including price fixing, bid rigging, and market allocation, which are deemed always to be harmful and to lack serious countervailing benefits. See generally Anderson et al., supra note 110.

${ }^{169}$ Armstrong, supra note 84 (Where exemplary damages might be available, the concern is even greater.)

${ }^{170}$ See Avishalom Tor, Unilateral, Anticompetitive Acquisitions of Dominance or Monopoly Power, 76 ANTITRUST L.J. 847, 852-53 (2010); see also Crane, supra note 119 at 3-4.

${ }^{171}$ Crane, supra note 119, at 4 ("courts tend to frame liability rules in a deliberately underinclusive manner ... [T] he recent tendency in US antitrust law has been to tilt both the procedural rules and su[bstan]tive liability rules toward underinclusion"). See also Huffman, supra note 11 (describing the position of Chicago School adherents with regard to antitrust enforcement). 
The countervailing concern regarding over-enforcement, from a behavioral exploitation theory of liability standpoint, is the chilling effect on desirable activity - most notably in advertising and related communication with regard to products and services. Advertising is designed to accomplish the same goals as is behavioral exploitation: to convince consumers to purchase or borrow from the advertising seller/lender, whether by bringing a new consumer into the market or by stealing a consumer from a competitor. Agencies, judges and commentators have noted the competitive concerns that flow from advertising restrictions. ${ }^{172}$ According to then-FTC Chairman Robert Pitofsky in 1995, "Advertising is a key source of price and other information and when competitors band together to restrict it, consumers lose."173 We recognize the concern that a theory of liability targeting behavioral exploitation might be deployed against pro-competitive advertising conduct. The response to this over-enforcement concern is two-fold.

First, behavioral exploitation is much more than advertising, which communicates and even persuades consumers with regard to the merchant's products. Behavioral exploitation targets established cognitive biases to induce decisions that consumers would not make but for the merchant's conduct. It describes a narrow class of conduct that has demonstrated effects on consumer decision-making. Second, the antitrust theory of behavioral exploitation recognizes the potential for over-enforcement concerns. It addresses those concerns by narrowly cabining the claim, including requiring proof of both general intent on the part of the defendant, and nonde minimis effects on the marketplace. ${ }^{174}$

Behavioral exploitation antitrust is limited to protect against overreaching in enforcement and the consequent dangers of false positives in enforcement. Criticisms of the theory nonetheless continue to exist. These include the limited ability of behavioral economics to inform antitrust in general; de minimis impacts of transaction-level conduct; and the possibility of consumer education to overcome the welfare effects of behavioral exploitation. We explore below the protections against over-enforcement and responses to those criticisms.

\section{INTENT AND EFFECTS}

Behavioral exploitation as a theory of antitrust liability relies on proof of: (1) general intent on the part of the merchant seller, and (2) an effect on the market. ${ }^{175}$ The required proof of general intent limits enforcement against innocent advertising conduct, mitigating chilling effect concerns from enforcement spillovers. A merchant might be held to have had sufficient intent to exploit a particular decision-making heuristic if it had studied the heuristic or paid for focus groups to learn the most effective way to increase consumer response. ${ }^{176}$ Proof that a merchant merely offered an array of products - though it might well nonetheless trigger the same heuristic and cause a market effect ${ }^{177}$ — would be insufficient to meet the requirement of proving intent.

\footnotetext{
172 See John E. Calfee, Fear of Persuasion: A New Perspective on Advertising and Regulation 17 (1997) (describing FTC positions on state-law limits on advertising); California Dental Ass'n v. FTC, 526 U.S. 756, 78485 (1999) (Breyer, J., dissenting) (agreeing with Federal Trade Commission and Ninth Circuit that advertising restrictions present competitive concerns).

${ }^{173}$ FTC Press Release, “Auto Dealers Association Settles Charges Over Alleged Advertising Boycott,” (Aug. 1, 1995).

${ }^{174}$ See Huffman, supra note 11, at 143.

${ }^{175} \mathrm{Id}$. at 143 .

${ }^{176}$ General intent is consistent with other standards in civil antitrust claims. See, e.g., United States v. Aluminum Co. of Am., 148 F.2d 416, 432 (2d Cir. 1945); Ronald A. Cass \& Keith N. Hylton, Antitrust Intent, 74 S. CAL. L. REV. 657, 661 (2001). A merchant has this mental state if it acts deliberately, knowing of the probable consequences of its actions.

${ }^{177}$ See Huffman, supra note 11, at 129-30.
} 
For example, sales manuals describing the benefits of opaque pricing strategies or setting out scripts for sales pitches might make strong evidence. Testimonial evidence by current or former employees may be available. One leading commentator on behavioral exploitation by merchants, Robert Cialdini, supported his own academic research with "a decidedly more entertaining program of systematic immersion into the world of compliance professionals - sales operators, fund-raisers, recruiters, advertisers, and others." His immersion program included observation, interviews, and review of written materials including sales manuals. ${ }^{178}$

The required proof of market effect serves to prevent overuse of behavioral exploitation in consumer, competitor, and government suits based on antitrust laws. ${ }^{179}$ An effect on the market requires a market failure that competition cannot be relied on to mitigate. That will occur where, for example, the course of behavioral exploitation assists a firm in establishing or maintaining a monopoly position. ${ }^{180}$ Bar-Gill notes, "sellers benefit from the divergence between perceived and actual benefits and between perceived and actual prices. They will design their products and prices to maximize this divergence." 181 The firm that is most effective at doing this will succeed and become dominant, unless other firms successfully imitate the strategy or consumers become sufficiently educated about the firm's conduct that it ceases to be a successful strategy.

The behavioral exploitation theory is not novel in requiring a market effect. A market effect requirement is nearly ubiquitous in antitrust, with the (increasingly narrow) exception of conduct held to be illegal per se. ${ }^{182}$ Such an effect existed in Eastman Kodak Co. v. Image Technical Services Inc. ${ }^{183}$, where on remand from the Supreme Court's holding that a lock-in sufficed to demonstrate market power, a jury concluded that Kodak did have a monopoly in the parts after-market despite the competitive market for its equipment. ${ }^{184}$ Proving that the effect flows from the behavioral exploitation, rather than some other cause, is a more complex problem, but no more so than the causal demonstration required throughout antitrust litigation focusing on a defendant's conduct. Private plaintiffs are saddled with a causation requirement as a matter of the antitrust standing doctrine, ${ }^{185}$ and all plaintiffs, including public enforcers, face functionally the same burden under the rule of reason. ${ }^{186}$

\footnotetext{
${ }^{178}$ Cialdini, Psychology of Persuasion, supra note 22, at xii-xiii.

179 The danger to be avoided includes, for example, the threat of treble damages liability in a suit by a purchaser suffering buyer's remorse. See Edwards, supra note 11, at 360 ("Could a consumer who impulsively purchases a candy bar and a copy of a gossip magazine claim that he has suffered a cognizable injury under the FTC Act?").

${ }^{180}$ Establishing, maintaining, or creating a dangerous probability of establishing a monopoly through a course of bad conduct implicates Section 2 of the Sherman Act, 15 U.S.C. $\S 2$.

${ }^{181}$ Bar-Gill, Competition and Consumer Protection, supra note 35, at 5. Bar-Gill works from the same assumption we do, that behavioral exploitation is a less expensive strategy than is product innovation.

182 See Chicago Bd. of Trade v. United States, 246 U.S. 231, 238 (1918) (defining the rule of reason to include examination of "the nature of the restraint and its effect, actual or probable"); Leegin Creative Leather Prods., Inc. v. PSKS, Inc., 551 U.S. 877, 886-87 (2007) (per se rules "eliminate[] the need to study the reasonableness of an individual restraint in light of the real market forces at work").

${ }^{183} 504$ U.S. 451 (1992).

${ }^{184}$ See Image Technical Servs., Inc. v. Eastman Kodak Co., 125 F.3d 1195, 1201 (9th Cir. 1997).

${ }^{185}$ See 15 U.S.C. $\S 4$ (harm must be "by reason of" a violation of the antitrust laws); Palmyra Park Hosp., Inc. v. Phoebe Putney Mem'1 Hosp., 604 F.3d 1291, 1299 (11th Cir. 2010) (holding that plaintiff's harm must be of the sort that makes the conduct illegal).

186 See, e.g., Brooke Grp., Inc. v. Brown \& Williamson Tobacco Corp., 509 U.S. 209, 225 (1993) (requiring a showing of a causal connection between conduct and an increase in prices); Cal. Dental Ass'n v. FTC, 526 U.S. 756 , 774-77 (1999) (government enforcement action where Court required proof that the complained of conduct caused a harmful effect).
} 


\section{CRITICISMS AND RESPONSES}

Others who have recognized the reality of behavioral exploitation have not taken the next step in proposing an antitrust remedy. A common recommendation is improved disclosure regulation, designed with a recognition of the realities of limited abilities to understand and use voluminous and complicated disclosures. ${ }^{187}$

\section{a. The Limits of Behavioral Antitrust}

Some criticize the entire practice of developing antitrust rules on the basis of behavioral law and economics teaching, arguing, among other things, that behavioral economics opens to door to undisciplined analysis. ${ }^{188}$ Some may see behavioral economics as "liberalism masquerading as economic thinking." "189 Among the critics of behavioral antitrust, Joshua Wright and Judd Stone most directly address the antitrust theory of behavioral exploitation. While acknowledging that behavioral economics offers interesting lessons in consumer behavior, and thus is, in theory, relevant for antitrust analysis, Wright and Stone contend that the methods of antitrust economics as currently practiced are sufficient to accommodate cognitive biases that influence consumer decisions. They also argue that behavioral economists have not produced theories that accommodate the many, sometimes conflicting, proven cognitive biases. ${ }^{190}$ This argument builds on Gregory Mitchell's argument that deviations from rational choice assumptions are non-uniform, so fail to produce a workable alternative theory. ${ }^{191}$

Those challenges might together be summed up as expressions of doubt as to the possibility of articulating a general theory of antitrust economics on the basis of currently available research. Such criticisms were more compelling before the increasingly substantial body of evidence supporting the existence of cognitive biases and demonstrating their operation in real world transactions had been developed. Empirical evidence is both more voluminous and more directly applicable to real-world settings, with much of it derived from actual market settings. ${ }^{192}$ Just as Posner once observed Chicago School antitrust economics began as isolated attacks on then-existing antitrust economics, ${ }^{193}$ behavioral antitrust is developing by starting with individual instances of observed deviations from rational choice theories. Where those theories

\footnotetext{
187 See James M. Lacko \& Janis K. Pappalardo, Improving Consumer Mortgage Disclosures, FTC Bureau of Economics Staff Report 121-28 (2007) ("Better disclosures are feasible").

${ }^{188}$ See Douglas Ginsburg \& Joshua D. Wright, Antitrust Sanctions, 6 ComPeTITION Policy INT’L 3 (2010).

${ }^{189}$ Rosch speech (characterizing the views of critics).

190 Others go further to question the viability of any policy measures pursued on the basis of the lessons from behavioral economics research. Gregory Mitchell was an early critic who argued in part that non-uniform deviations from rationality assumptions suggested that reforms on the basis of behavioral lessons should be modest. See Gregory Mitchell, Why Law and Economics' Perfect Rationality Should Not Be Traded for Behavioral Law and Economics' Equal Incompetence, 91 GEO. L. J. 67 (2002). Richard Epstein argued that "notwithstanding the potential resource misallocations that may flow from these errors" in failing to optimize individual utility, the law should not remedy those misallocations outside of preventing fraud. Richard Epstein, Human Errors and Market Corrections, 73 U. CHI. L. REV. 111, 118-120 (2006). Matthew Edwards expressed concern with the necessarily paternalistic nature of policymaking on the basis of observed bounds on consumer rationality. See Matthew Edwards, The FTC and New Paternalism, 60 ADMIN. L. REV. 323, 333-36 (2008) (canvassing critical reactions). Tom Brown and Lacey Plache argued that empirical evidence is insufficient to support many of the policy recommendations that have been advocated on the basis of behavioral economics research. See Tom Brown \& Lacey Plache, Paying With Plastic: Maybe Not So Crazy, 73 U. CHI. L. REV. 63, 66 (2006).

${ }^{191}$ See Mitchell, supra note 190.

192 See Reeves \& Stucke, supra note 22, at 1538.

${ }^{193}$ Richard Posner, The Chicago School of Antitrust Analysis, 127 U. Pa. L. Rev. 925, 926 (1979).
} 
are robust, they should influence the development of legal rules, such as the creation of the behavioral exploitation theory we advance here.

\section{b. Behavioral Exploitation is De Minimis}

A second challenge to the expansion of antitrust liability to cover instances of behavioral exploitation is that the harm in any one instance of behavioral exploitation is transaction level harm, and its regulation is the stuff of the law of contract and consumer protection, vis-à-vis the market in which the transaction occurs the harm frequently will be de minimis, producing no harm to "competition." This argument has been leveled against efforts to regulate tortious conduct through antitrust ${ }^{194}$ and against efforts to regulate deception through antitrust. ${ }^{195}$ The $d e$ minimis challenge applies equally to behavioral exploitation, where harm occurs at the transaction level. A single $\$ 250,000$ mortgage transaction will not impact competition in a market for home mortgage lending that in 2006 was worth $\$ 2.5$ trillion. ${ }^{196}$

Arguments that behavioral exploitation should be regulated under the law of consumer protection are ultimately unconvincing. First, comparisons to tort law and deception are misplaced. Both of those fields are well regulated under common law and federal and state statute. Adding an antitrust remedy is at best redundant and possibly threatens inefficient overenforcement. Behavioral exploitation is regulated only marginally under common law and federal and state consumer protection laws. In the 2002 study of the welfare effects of predatory lending that we discuss above, Stein noted that the conduct causing welfare effects was entirely legal. ${ }^{197}$ An antitrust remedy targeting this conduct would not be redundant. In its absence, we have a status quo characterized by inefficient under-enforcement.

Second, the de minimis argument proves both too much. Nearly all of antitrust is concerned with conduct in which any single instance would have a de minimis impact on competition. ${ }^{198}$ Consumer transactions, in the ordinary course, must be aggregated to produce the kind of market-wide harm that supports antitrust treatment. ${ }^{199}$ Where a course of conduct impacts a large enough number of individually de minimis transactions, it will produce the kind of market effect that justifies antitrust intervention. ${ }^{200}$

\section{c. Consumer Education Is a Cure}

A third criticism is that competition will lead to consumer education that will mitigate harms from behavioral exploitation. Implicit in this criticism is the concern that providing a remedy removes or limits consumers' incentives to become educated with regard to the transactions in which they are engaged.

Consumer education relies on either third-party intervention; competitor intervention; or sufficient repeat interactions, causing consumers to self-educate. Durable goods markets or markets for long-term financial contracts are unlikely to permit consumer self-education.

\footnotetext{
${ }^{194}$ See Joshua D. Wright, Antitrust Analysis of Category Management: Conwood v. U.S. Tobacco Co., 17 S. CT. ECON. REV. 311, 332 \& n.69 (2009) (analyzing antitrust claims based on vandalizing competitor retail equipment).

${ }^{195}$ See IIIB Herbert Hovenkamp, Antitrust Law 782d (3d ed. 2006) (deceptive disparagement of a rival has a de minimis competitive impact).

${ }^{196}$ Financial Crisis Inquiry Report, supra note 70 , at 70 (noting $\$ 600$ billion subprime mortgage originations representing $23.5 \%$ of the total mortgage originations in 2006).

${ }_{197}$ See Stein, supra note 44.

${ }^{198}$ The exception is merger review, in which the conduct of concern is two firms' combining to create an unwieldy level of concentration.

${ }^{199}$ See Huffman, supra note 11, at $142 \mathrm{n} .211$ (single instance of price fixing is de minimis).

${ }^{200}$ Conversely, nobody seriously could argue that all conduct with a substantial competitive impact represents an antitrust harm. Blowing up a competitor's factory or assassinating a competitor's chief executive would impact competition, but neither is believed to present antitrust harms.
} 
Competitor education through advertising is a possibility, but where a firm achieves dominance through behavioral exploitation, competitors will not sufficiently understand the dominant merchant's marketing strategy to create effective educational advertising and/or will not have sufficient market presence for educational advertising to have an impact. A small local lending institution would have found it impossible to achieve sufficient advertising distribution to make a campaign challenging conduct by a major national lender like Countrywide Financial worth the candle.

Too, behavioral exploitation, unlike its cousin, deception, is subtle. If, for example, the product in question is a long-term lending contract, and the merchant exploits the consumer's tendency to over-optimism ("you are sure to have earned a raise by the time the interest rate adjusts"), it is not clear what educational advertising would undermine the merchant's conduct. The relevant information would be "you are not statistically likely to have earned that raise" but any such statement is at best likely to be ineffective, and at worst may offend.

Competitor education is an unreliable cure for the market failure behavioral education causes for another reason. Competitors are likely to find it a better strategy to imitate, rather than to undermine, behavioral education by a merchant. Richard Posner recognized this phenomenon in the context of markets for harmful products, like cigarettes. ${ }^{201}$ Bar-Gill demonstrated that little advantage is to be gained by a competitor from consumer education, apart from the first-mover advantage of being the first firm fully to disclose product attributes or pricing. Xavier Gabaix and David Laibson go further, arguing that, "it is not possible to profitably lure ... myopes . . to non-exploitative firms." ${ }^{, 02}$ This demonstrates the second basis for antitrust concern - concerted behavioral exploitation, which can occur even in a market without a dominant firm. ${ }^{203}$ Concerted exploitation can either be through actual agreement or consciously parallel conduct, although under the current state of the law of concerted conduct, consciously parallel conduct does not establish that element of the offense. ${ }^{204}$

We can therefore expect market failures caused by behavioral exploitation to be sustained over a sufficiently large time horizon to lead to both intra-market and external harm. With specific regard to the home mortgage marketplace, the targeted regulation that exists either has been proved, or can be expected to be, insufficient to prevent or remedy those failures and harms.

\section{MOVING TO BEHAVIORAL EXPLOITATION ANTITRUST}

Antitrust exists to cure for market failures that arise where one firm, or a group of firms, is (are) able to profit at the expense of consumers by charging quality-adjusted prices exceeding what the consumers would pay, but for the conduct on the part of the firm(s). Behavioral exploitation antitrust operating in the consumer subprime mortgage industry would allow the application of antitrust remedies to transaction-level conduct in consumer subprime mortgage lending, if it is undertaken with general intent and on a broad enough scale to produce a market effect. In this final Part we argue antitrust standards should be relaxed to permit resort to

\footnotetext{
${ }^{201}$ See Richard A. Posner, Regulation of Advertising by the FTC, Evaluative Studies, vol. 11, AM. ENTER. INST. FOR Pub. POLICY RESEARCH (1972).

202 Xavier Gabaix \& David Laibson, Shrouded Attributes, Consumer Myopia, and Information Suppression in Competitive Markets, MIT DEP'T OF ECON. WORKING PAPER (2005), available at papers.ssrn.com/abstract=728545.

${ }^{203}$ Concerted conduct potentially implicates Section 1 of the Sherman Act, 15 U.S.C. $\S 1$.

${ }^{204}$ See Bell Atlantic Corp. v. Twombly, 550 U.S. 544 (2007).
} 
antitrust review and remedies in the market for consumer subprime mortgages and closely analogous marketplaces.

Evidence regarding the consumer subprime mortgage industry prior to the 2007 financial crisis suggests that, even under a definition of harmful conduct that includes behavioral exploitation, antitrust remedies would be difficult to achieve under the current state of doctrine. The subprime mortgage market lacked sufficient concentration and sufficient barriers to entry to satisfy modern standards for challenging a merger as "tending to create a monopoly." A lack of evidence that market participants reached either express or implied agreement, rather than acting independently or tacitly colluding, undermines efforts to pursue remedies under Sherman Act, section 1. And insufficient market share by even Countrywide Financial, the most substantial player in the consumer subprime mortgage market, coupled with insufficient barriers to entry, makes enforcement against dominant firm conduct under Sherman Act, section 2, unlikely. ${ }^{205}$

All three avenues of analysis should remain available should the market structure or observed conduct change sufficiently to meet the existing requirements. A course of mergers or failures might well render the subprime mortgage market sufficiently concentrated to present both dominant firm and monopolization by merger concerns, and evidence of actual agreement would implicate section 1 . Other avenues exist to a closely cabined course of broader enforcement intended to prevent and to remedy known welfare effects in this and similar industries.

Standards for blocking and remedying harm caused by a merger might be broadened to encompass transactions not leading to a monopoly position, as traditionally defined. There is an increasing understanding that market share is a highly imperfect proxy for the welfare harm from a merger. ${ }^{206}$ Such an understanding would permit courts to block a merger on a demonstration of actual or likely welfare effects through unilateral or coordinated conduct. This approach to merger review allows a challenge that increases the likelihood of harm regardless of structural changes in the market. Under this approach, a relative lack of concentration and low barriers to entry would not hinder merger challenges claiming incipient behavioral exploitation.

The long-standing rule for proving agreement under section 1, which excludes tacit collusion, has been the subject of occasional challenge in the courts and frequent questioning by commentators. It is well understood that tacitly collusive conduct presents the same welfare effects, as does agreement. For that reason, noted judges and commentators have questioned a definition of agreement that is too narrow to encompass such conduct. ${ }^{207}$ The law governing tacit collusion has been firmly established and recently reaffirmed. ${ }^{208}$ It also rests on a sound basis: imposing liability for profit-maximizing interdependent conduct dampens incentives for vigorous competitive activity. Any relaxation of the strict requirement for proving agreement under section 1 to allow challenges to tacit collusion should be narrowly cabined to avoid overreaching in enforcement. We believe a narrow rule permitting challenges to tacitly collusive behavioral exploitation in markets that are shown to be subject to enduring "lemons equilibria," like that for consumer subprime mortgage lending, serves the needs of permitting antitrust

\footnotetext{
${ }^{205}$ See supra notes $127-139$ and accompanying text.

${ }^{206}$ For example, the revised Horizontal Merger Guidelines consider "market shares and concentration in conjunction with the reasonably available and reliable evidence for the ultimate purpose of determining whether a merger may substantially lessen competition." Merger Guidelines, supra note 125, at $\S 5$.

${ }^{207}$ See Max Huffman, The Necessity of Pleading Elements in Private Antitrust Conspiracy Claims, 10 U. PA. J. BUS. \& EMP. L. 627, 646-49 (2008) (discussing authorities).

208 See Bell Atlantic Corp. v. Twombly, 550 U.S. 544 (2007).
} 
enforcement where other regulatory approaches have proved ineffective while not inappropriately chilling aggressive unilateral competitive conduct.

The limited broadening of existing approaches to antitrust enforcement discussed in the prior paragraphs brings to bear the benefits of belts and suspenders enforcement, competition among enforcers, and the unique incentives facing private plaintiffs, to regulating excesses in consumer subprime mortgage markets like those that led to the 2007 financial crisis. Another approach is to rely on broader language in the Federal Trade Commission Act to base a broader theory of enforcement against behavioral exploitation antitrust. Instead of enforcing sections 1 and 2 of the Sherman Act, the Federal Trade Commission enforces a broad prohibition of "unfair methods of competition." Although there is value generally to employing the FTC Act to its fullest extent consistent with the efficiency principles underlying antitrust enforcement, the FTC Act lacks a private right of action and a competitive enforcement regime. It offers few of the advantages of antitrust enforcement generally.

\section{CONCLUSION}

The grass-roots cause of the 2007 financial crisis was the market for consumer home mortgages. That market was rife with failures, including deception and behavioral exploitation. The particular nature of mortgage lending - in the words of the CEO of one lender, its "bewildering array" of terms and fees ${ }^{209}$ — created a particularly vulnerable industry in which behavioral exploitation could flourish. In turn, the market provided substantial short-term success for firms engaged in conduct with well-documented welfare effects. The regulatory status quo ante consumer subprime mortgage lending was inadequate. Mortgage lending regulation is concerned with conduct at the transactional level. That regulation proved insufficient to remedy effects that were felt market, and economy-wide. Repeat-player lenders could successfully avoid regulation by complying with the letter of the law while relying in large part on inexperienced consumers' ability to understand complicated terms.

Our argument above operates under several premises. Behavioral exploitation disturbs efficient resource allocation, as consumers would otherwise act differently, but for the conduct. Behavioral exploitation occurred in the mortgage lending industry leading up to the 2007 financial market crisis, and in the absence of regulation realistically designed to prevent it, persists today. The 2007 financial market crisis was caused, in large part, by failures - caused in part by inefficient resource allocation-in consumer home mortgage lending firms. Antitrust law exists to prevent market failures; thus, antitrust law could and should be used to prevent the pervasive type of market failures that led to the 2007 financial crisis.

Ours is a far-reaching argument. Many have recognized the welfare effects in behavioral exploitation, including in subprime lending. A handful of writers seem to agree that transaction level harms should give rise to antitrust remedies, although that exceeds the bounds of antitrust doctrine and the mainstream of antitrust scholarship. However, the market failures caused by behavioral exploitation at the individual transactional level had broad welfare effects both in the market and external to it. In the aggregate, those individual transactions presented competitive harm raising antitrust concerns. The impact of behavioral exploitation in the mortgage lending industry was not and is not confined to individual transactional level concerns. Rather, in order for firms undertaking to profit from the behavioral exploitation of the type we suggest occurred

${ }^{209}$ Testimony of Scott Stern, CEO of Lenders One, United States Senate Banking, Housing and Finance Committee (April 10, 2008). 
in mortgage lending practices, a firm must consistently and systemically engage in behavioral exploitation.

Rather than the individual transactional level focus of disclosure statutes in place today, antitrust provides an avenue to regulate the mortgage industry at the firm level. In turn, by regulating firm-level conduct, antitrust regulation will remove incentives for a particular firm to engage in "mortgage malpractice," which success and profits require more than just one transaction. Indeed, by removing incentives to engage in "bad" conduct at both transactional and firm levels, and even encouraging competitors to monitor one another's conduct, antitrust may be an elegant and even superior solution to the grass-roots problems that ultimately led to massive economic dislocations that were exposed in the 2007 financial crisis. 